\title{
Biodegradable Peptide Polymers as Alternatives to Antibiotics Used in
}

\section{Aquaculture}

Pengcheng Ma, ${ }^{1}$ Yueming Wu, ${ }^{2}$ Weinan Jiang, ${ }^{2}$ Ning Shao, ${ }^{2}$ Min Zhou, ${ }^{1}$ Yuan Chen, ${ }^{2}$ Jiayang Xie, ${ }^{2}$ Zhongqian Qiao, ${ }^{2}$ and Runhui Liu ${ }^{*}, 1,2$

${ }^{1}$ State Key Laboratory of Bioreactor Engineering, East China University of Science and Technology, Shanghai 200237, China,

${ }^{2}$ Key Laboratory for Ultrafine Materials of Ministry of Education, Frontiers Science Center for Materiobiology and Dynamic Chemistry, Research Center for Biomedical Materials of Ministry of Education, School of Materials Science and Engineering, East China University of Science and Technology, Shanghai 200237, China

Correspondence should be addressed to R.L. (rliu@ecust.edu.cn)

\begin{abstract}
The pressure of antimicrobial resistance has forced many countries to reduce or even prohibit the use of antibiotics in feed. Therefore, it is in urgent need to develop alternatives to antibiotics to control infectious diseases in feed and aquaculture. To address this long-lasting challenge, we prepared peptide polymers that display potent and broad-spectrum activity against common pathogenic bacteria in aquaculture, low hemolysis and low cytotoxicity, and doesn't induce bacteria to develop resistance or cross resistance to antibiotics. The optimal peptide polymer demonstrates strong in vivo therapeutic potential in an adult zebrafish infection model. Moreover, the optimal peptide polymer is biodegradable by enzyme into single amino acids and dipeptides to totally lose antibacterial activity and, therefore, will not cause antimicrobial selective pressure. Our study suggests that peptide polymers are promising alternatives to antibiotics in aquaculture and open new avenues to address the global challenge of antimicrobial resistance.
\end{abstract}

\section{Introduction}

With the increasing demand of animal protein nutrition, intensive animal production is growing very fast. To meet the production volume requirement in aquaculture, poultry and livestock, Food and Drug Administration (FDA) approved the use of antibiotics in feed in $1950 \mathrm{~s}^{1}$. Since then, food animal industry more and more relies on the use of antibiotics ${ }^{2,3}$. The global consumption of antimicrobials, majorly antibiotics, in food animals was 131,109 tons in 2013 , and estimated to be 200,235 tons by $2030^{4}$. However, antibiotic residues in food animals 
will be transmitted to the human through the food chain, destroying human microbiome and inducing bacteria to develop drug resistance (Fig 1a) $)^{5-7}$. It is also noteworthy that many antibiotics are eventually discharged into the environment especially for aquaculture ${ }^{8-11}$. A recent investigation reveals a high level content of antibiotics, such as sulfonamides, in the surface water in different countries, which will cause serious antimicrobial resistance problems (Fig 1b) ${ }^{12-14}$. Antibiotic residues in water will also spread in the ecosystem, further exerting selective pressure on environmental microorganisms and accelerating the occurrence and evolution of antibiotic resistant bacteria (ARB) and antibiotic resistant genes (ARGs), which will cause a great potential threat to animal and human health (Fig 1a). It is estimated that drug-resistant bacteria will cause about 10 million deaths per year by 2050 , if no effective action is taken immediately ${ }^{15}$. As early as 2006, the European Union announced a total ban on the use of antibiotics in feed. Subsequently, the United States, Japan, China and other countries successively promulgated various policies to reduce or even prohibit the use of antibiotics in feed ${ }^{16-20}$. It is a consensus that it is imperative to prohibit the massive use of antibiotics all over the world in food animals, including aquaculture.

In order to replace the use of antibiotics in aquaculture, multiple strategies have been actively explored such as vaccines ${ }^{21,22}$, biological control ${ }^{23-26}$, antimicrobial peptides ${ }^{27,}$ 28, medicinal herbs extract ${ }^{29}, 30$ and nanoparticles ${ }^{31,32}$. However, none of these strategies meet the requirement for antibiotic substitution up to date. It is highly desired that antibiotic substitutes in aquaculture have broad spectrum activity, potent activity against drug-resistant bacteria, low cost in production, excellent biocompatibility, and most critically fully biodegradability to give degraded products that completely lose antibacterial activity and will not cause antimicrobial selective pressure in organisms and the environments. It's worth mentioning that degradable antibacterial polymers have been studied, such as the acrylate copolymers degradable in aqueous solution into lower molecular weight oligomers that have decreased antibacterial activity ${ }^{33}$, antibacterial polyionenes degradable rapidly at $\mathrm{pH} 10$ and slowly under neutral or acidic conditions ${ }^{34}$, and antibacterial polycarbonate degradable under physiological conditions ${ }^{35}$. However, degradable antimicrobials as need for antibiotic substitution in aquaculture refer to antimicrobials that are fully degradable to very basic components such as single amino acid in relative short period, rather than degradable to large fragments because large fragments can still have moderate antibacterial activity to cause antimicrobial resistance and antimicrobial selective pressure. Colistin is a representative host defense peptide (HDP) that has ever been used as an animal feed additive for many years. At present, colistin has been banned as a feed additive in China and Thailand because colistin cannot be completely degraded by enzymes existing in the environment and animals, and the use of colistin in feed is found to accelerate the dissemination of the first mobile mechanism of colistin resistance, termed MCR-1, in 
animals and then in human beings ${ }^{17,36,37}$. Up to date, no successfully replacement of antibiotics is available in aquaculture.

Synthetic mimics of HDP have shown broad-spectrum antibacterial activity ${ }^{38-50}$, and can be promising candidates of antibiotic substitutes if ideally degradable into individual residues without antimicrobial activity. In this work, we design antibacterial peptide polymers that are composed of lysine and serine in different proportions and are easily synthesized in minutes via the fast ring-opening polymerization on amino acid $N$-carboxyanhydride (NCA) using lithium hexamethyldisilazide (LiHMDS) as the initiator (Fig 1c ${ }^{51,52}$. Among these peptide polymers, $\alpha$-Poly-L-lysine composed entirely of lysine is well known to have antibacterial activity but very limited application as an antimicrobial agent due to its significant cytotoxicity. Therefore, we replace part of the positively charged lysine residue with the hydrophilic serine residue to reduce the cytotoxicity of resulting peptide polymers and the acute toxicity to zebrafish, while having the minimal impact on antibacterial activity. The optimal peptide polymers meet all the desired properties of antibiotic substitutes in aquaculture, such as exhibiting excellent antibacterial activity against common pathogenic bacteria in aquaculture and significantly improving the survival rate of zebrafish after Vibrio anguillarum infection, and do not induce bacteria to develop antibacterial resistance. Moreover, the peptide polymers are biodegradable into individual amino acids and dipeptides that have no antibacterial activity and, therefore, will not cause antimicrobial resistance and antimicrobial selective pressure in organisms and the environment. Aforementioned advantages, all together, imply potential application of these peptide polymers as substituents of antibiotics in aquaculture. 
a

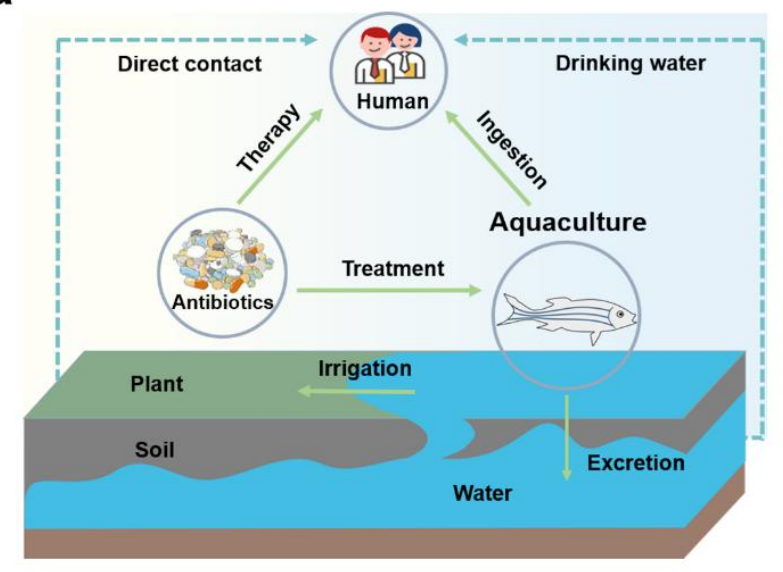

b

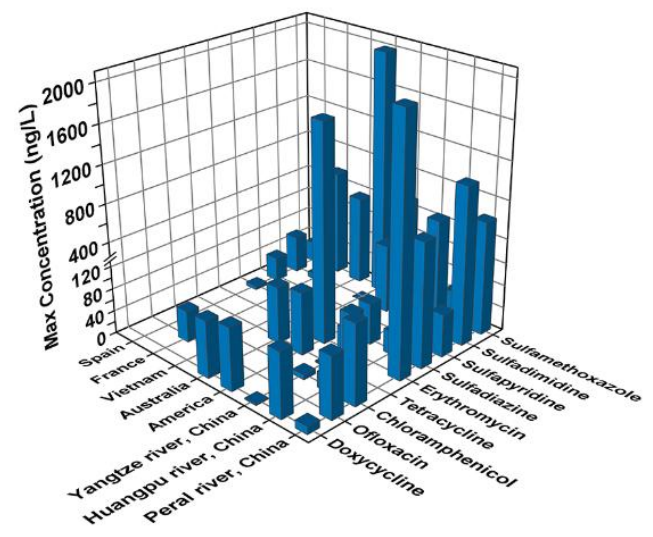

C

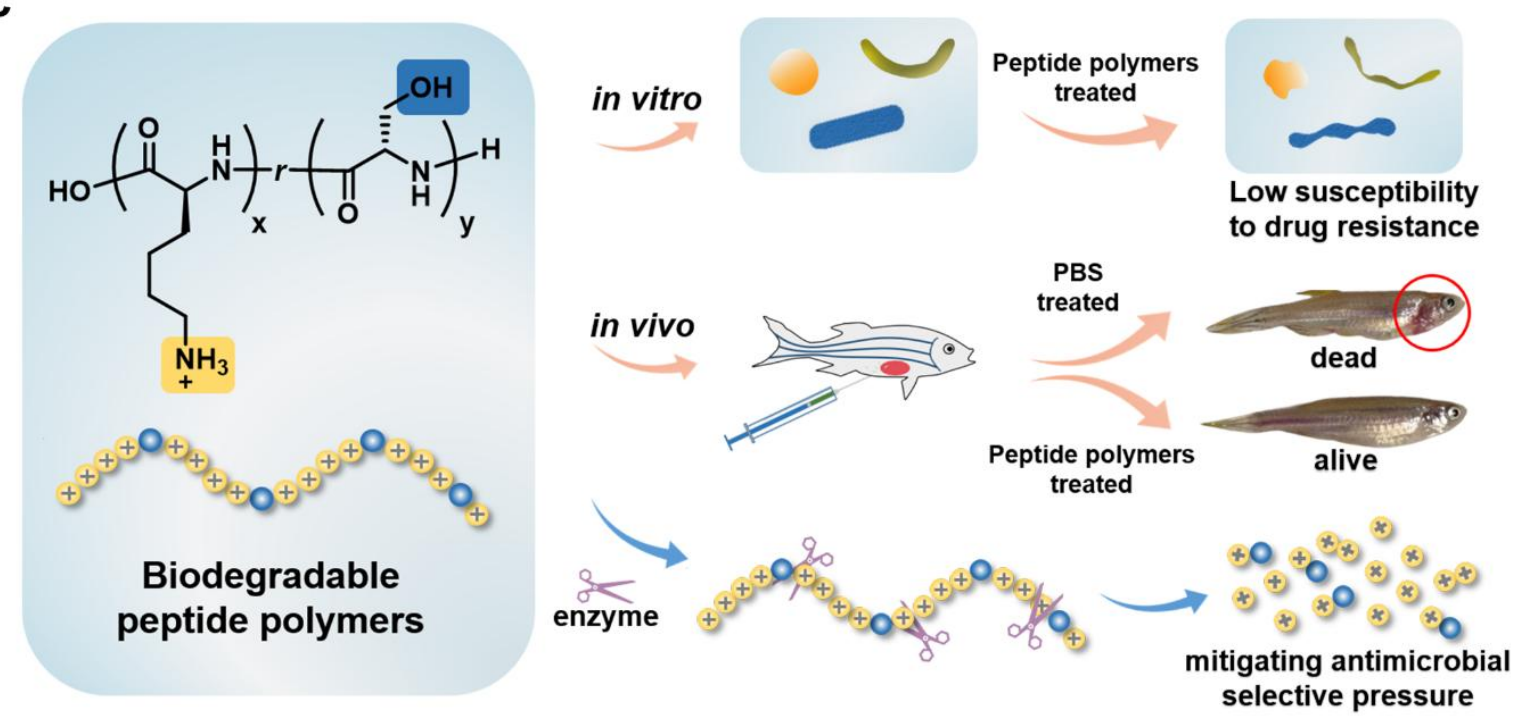

Fig 1. a) The massive use of antibiotic in aquaculture results in antibiotic contamination in the environment, antimicrobial resistance and antimicrobial selective pressure. b) Maximum concentration of antibiotic residues in surface water of various countries. c) Biodegradable peptide polymers as alternatives to antibiotics by displaying potent antibacterial activity in vitro and in vivo, low susceptibility to induce drug resistance and antimicrobial selective pressure.

\section{Results}

Peptide polymers (KxSy) were synthesized from the ring-opening polymerization on a mixture of Ne-tertbutyloxycarbonyl-L-lysine (Boc-L-Lys) NCA (Fig S1) and O-(tert-butyl)-L-serine (tBu-L-Ser) NCA (Fig S2) at variable ratios using LiHMDS as the initiator, followed by treatment with trifluoroacetic acid to remove protecting groups (Fig 2a). The obtained peptide polymers have narrow dispersities $(\nexists=1.1-1.2)$ and similar chain length $(D P=19-22)$ according to the characterization by gel permeation chromatography (GPC) (Fig 2b, GPC traces in Fig 2c and Fig S9-13). By modifying the C-terminus of peptide polymers with tert-butyl benzylamine and analyzing with nuclear magnetic resonance (NMR), we further determined the DP (similar to the result from GPC analysis) and the ratio of lysine to serine in the final peptide polymers (Fig 2b, 2d and Fig S3-7). 
Antibacterial studies showed that three peptide polymers $\left(\mathrm{K}_{21}\left(\alpha\right.\right.$-Poly-L-lysine), $\left.\mathrm{K}_{19} \mathrm{~S}_{2}, \mathrm{~K}_{18} \mathrm{~S}_{4}\right)$ had potent activities against multiple food animal-associated pathogens, including Staphylococcus aureus (S. aureus), Escherichia coli (E. coli) and Pseudomonas aeruginosa (P. aeruginosa) as representative common pathogenic bacteria, Vibrio alginolyticus (V. alginolyticus), Vibrio anguillarum (V. anguillarum) and Vibrio parahaemolyticus (V. parahaemolyticus) as common pathogenic bacteria in aquaculture, Salmonella pullorum (S. pullorum), Salmonella typhimurium (S. typhimurium) and Salmonella anatum (S. anatum) as common pathogenic bacteria in poultry, Mannheimia haemolytica (M. haemolytica), Streptococcus suis (S. suis) and Salmonella choleraesuis (S. choleraesuis) as common pathogenic bacteria in livestock (Fig 2e). The minimum inhibitory concentration (MIC) of three most active peptide polymers $\left(\mathrm{K}_{21}, \mathrm{~K}_{19} \mathrm{~S}_{2}, \mathrm{~K}_{18} \mathrm{~S}_{4}\right)$ were in the range of 0.78-50 $\mu \mathrm{g} / \mathrm{mL}$. In addition, all these peptide polymers showed negligible (less than $0.2 \%$ ) hemolysis on human red blood cells at a peptide polymer concentration up to $2000 \mu \mathrm{g} / \mathrm{mL}$ (Fig $2 \mathrm{f}$ ). Peptide polymers $\mathrm{K}_{18} \mathrm{~S}_{4}, \mathrm{~K}_{16} \mathrm{~S}_{6}$ and $\mathrm{K}_{13} \mathrm{~S}_{8}$ all displayed low cytotoxicity against mammalian cells even at a peptide polymer concentration of $200 \mu \mathrm{g} / \mathrm{mL}$, using COS-7 as a model (Fig $2 \mathrm{~g}$ ). $\mathrm{K}_{18} \mathrm{~S}_{4}$ displayed the best overall performance and was selected as the optimal peptide polymer for further studies. 
a

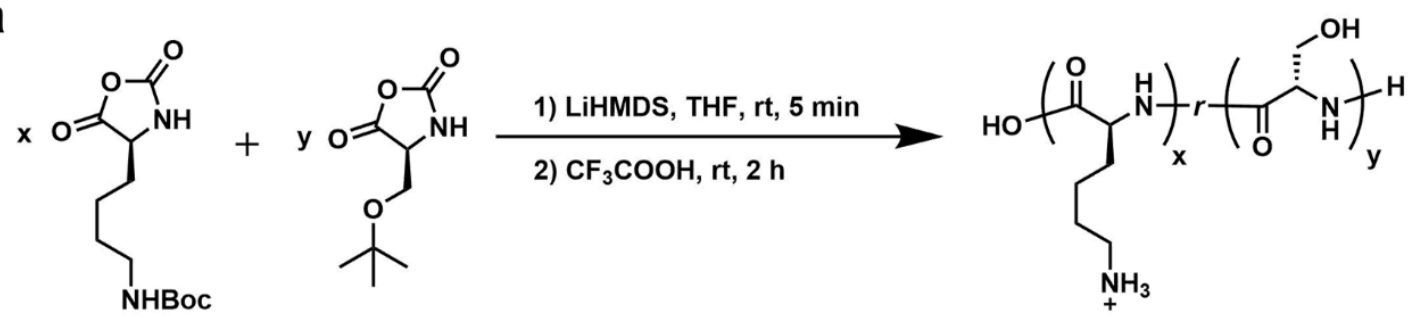

Peptide polymer : $\mathrm{K}_{\mathrm{x}} \mathrm{S}_{\mathrm{y}}$

b

\begin{tabular}{cccccc}
\hline \multirow{2}{*}{ Polymer } & \multirow{2}{*}{ Composition } & \multicolumn{2}{c}{ GPC characterization } & \multicolumn{2}{c}{ NMR characterization } \\
& & $M_{n}$ & $D$ & $D P$ & $D P$ \\
\hline P1 & $\mathrm{K}_{21}$ & 4400 & 1.15 & 19 & 21 \\
P2 & $\mathrm{K}_{19} \mathrm{~S}_{2}$ & 4300 & 1.15 & 20 & 21 \\
P3 & $\mathrm{K}_{18} \mathrm{~S}_{4}$ & 4100 & 1.15 & 20 & 22 \\
P4 & $\mathrm{K}_{16} \mathrm{~S}_{6}$ & 4200 & 1.14 & 21 & 22 \\
P5 & $\mathrm{K}_{13} \mathrm{~S}_{8}$ & 4200 & 1.14 & 22 & 21 \\
\hline
\end{tabular}

d

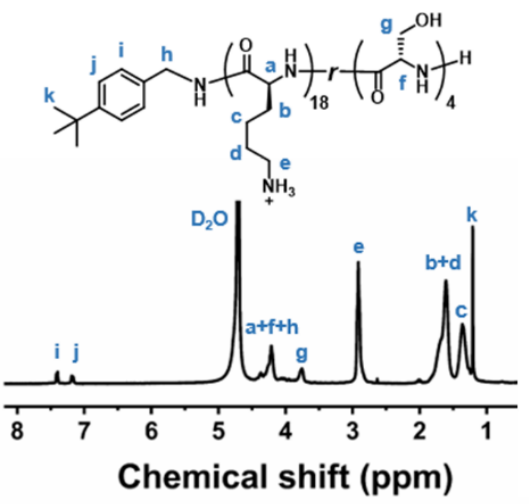

f

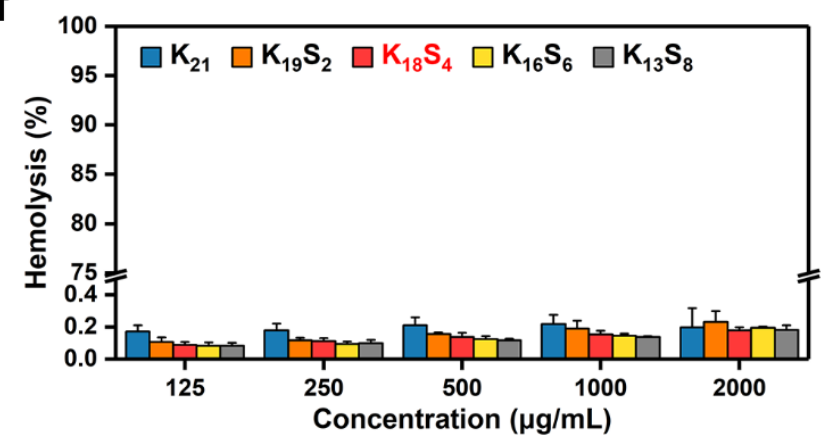

e

g
C

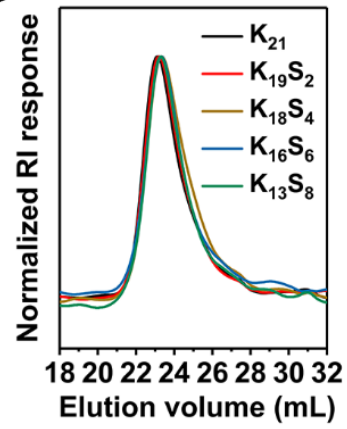

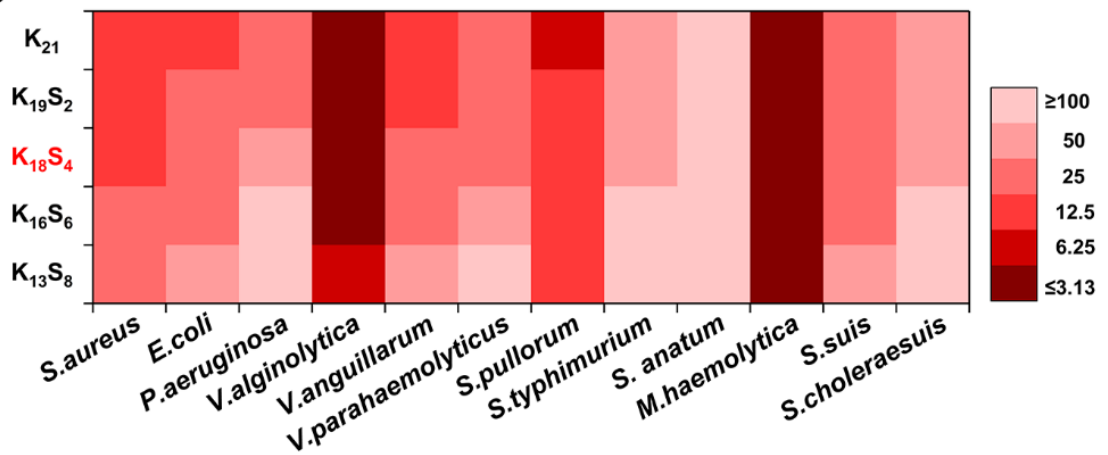

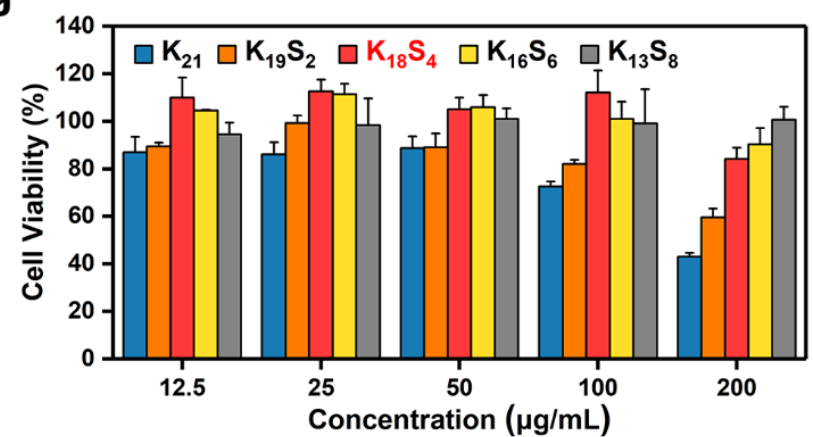

Fig 2. a) Synthesis of peptide polymers. b) GPC characterization of peptide polymers at the sidechain NHBoc protected stage using DMF as the mobile phase. $M_{\mathrm{n}}$ is the number average molecular weight. $\oslash$ is the dispersity index; $D P$ is the degree of polymerization. NMR characterization was conducted on deprotected peptide polymers bearing N-terminal tert-butyl-benzylamine. c) GPC trace of peptide polymers. d) Representative NMR spectrum of peptide polymers. e) Antibacterial activity of peptide polymers against common pathogenic bacteria in aquaculture, poultry and livestock. f) Hemolysis of peptide polymers on hRBCs, all data were presented as the mean \pm SD $(n=3)$. g) Cytotoxicity of peptide polymers on COS-7 cells, all data were presented as the mean \pm $\mathrm{SD}(\mathrm{n}=3)$.

We continued to examine the antibacterial activity of $\mathrm{K}_{18} \mathrm{~S}_{4}$ on common pathogenic bacteria in aquaculture, 
using aquaculture antibiotics thiamphenicol and sulfadimethoxine for comparison (Fig $3 \mathrm{a}$ ). $\mathrm{K}_{18} \mathrm{~S}_{4}$ displayed potent activities against all these pathogens with MIC in the range of 3.13-25 $\mu \mathrm{g} / \mathrm{mL} ; \mathrm{K}_{18} \mathrm{~S}_{4}$ was also bactericidal with minimum bactericidal concentration (MBC) identical to its MIC for most bacteria. The overall antibacterial activity of $\mathrm{K}_{18} \mathrm{~S}_{4}$ was superior to thiamphenicol and sulfadimethoxine, especially for MBC. We also examined the activity of $\mathrm{K}_{18} \mathrm{~S}_{4}$ against fungi, though fungi are not major pathogens in aquaculture. $\mathrm{K}_{18} \mathrm{~S}_{4}$ displayed potent activity against $C$. neoformans ( $\mathrm{MIC}=1.56-3.13 \mu \mathrm{g} / \mathrm{mL}$ for all three strains) comparable to amphotericin $\mathrm{B}$, but no obvious activity against $C$. albicans at a concentration up to $200 \mu \mathrm{g} / \mathrm{mL}$ (Table S1). In the acute toxicity test on adult zebrafish, the $\mathrm{LC}_{50}$ (the median lethal concentration) value of $\mathrm{K}_{18} \mathrm{~S}_{4}$ was $98.14 \mu \mathrm{g} / \mathrm{mL}$ (Fig 3b, Table S2), which was much higher than the MIC and MBC values of $\mathrm{K}_{18} \mathrm{~S}_{4}$ and indicated selective antibacterial properties of $\mathrm{K}_{18} \mathrm{~S}_{4}$. Compared with $\alpha$-Poly-L-lysine $\left(\mathrm{LC}_{50}\right.$ of $\left.\mathrm{K}_{21}: 19.61 \mu \mathrm{g} / \mathrm{mL}\right)$, the acute toxicity of $\mathrm{K}_{18} \mathrm{~S}_{4}$ to adult zebrafish was also significantly reduced (Table S2). A further time-killing kinetics study on $\mathrm{K}_{18} \mathrm{~S}_{4}$ against Grampositive bacteria S. aureus and Gram-negative bacteria E. coli and V. anguillarum (a representative of the common pathogenic bacteria in aquaculture) revealed a quick killing of bacteria at $2 \times \mathrm{MIC}$ concentration of $\mathrm{K}_{18} \mathrm{~S}_{4}$, such as the complete killing of $V$. anguillarum within 30 minutes (Fig 3c). The bacteria-killing of $\mathrm{K}_{18} \mathrm{~S}_{4}$ was much faster than that of conventional antibiotic thiamphenicol, indicating advantages of $\mathrm{K}_{18} \mathrm{~S}_{4}$ in treating aquacultureencountered bacterial infections.

To examine if bacteria can develop resistance to the peptide polymers, we treated Gram-positive $S$. aureus and Gram-negative $E$. coli with $\mathrm{K}_{18} \mathrm{~S}_{4}$ at $0.5 \times \mathrm{MBC}$ concentration continuously, and found that none of the bacteria developed resistance against $\mathrm{K}_{18} \mathrm{~S}_{4}$ even after continuous treatment for 888 and 1152 generations of S. aureus and E. coli, respectively (Fig 3d, Fig S14-15). In sharp contrast, S. aureus and E. coli developed resistance toward antibiotics quickly, displaying 824-fold resistance against norfloxacin for S. aureus and 64-fold resistance against ampicillin for E. coli. Moreover, cross-resistance was observed on the norfloxacin-treated 264th generation $S$. aureus against gentamycin and thiamphenicol, and on the ampicillin-treated 504th generation E. coli against penicillin and kanamycin (Fig 3e), which reflects the serious problem of cross-resistance among antibiotics used in aquaculture. Fortunately, cross-resistance was not observed on $\mathrm{K}_{18} \mathrm{~S}_{4}$-treated 888th generation $S$. aureus and 1152th generation E. coli against antibiotics commonly used in aquaculture (Fig 3d), which indicates a superior advantage of peptide polymers as potential substitutes of antibiotics in aquaculture, minimizing the antimicrobial resistance in the environments.

Even if an antibacterial agent, such as $\mathrm{K}_{18} \mathrm{~S}_{4}$, shows low tendency to induce antimicrobial resistance, full degradability is still highly desired for antibiotic substitutes in aquaculture. The massive use and subsequent 
discharge of the antimicrobial agents to the environment may cause antimicrobial selective pressure and disruption of balance of the complicated microbial system in the environment, which is a big concern in massive use of antibiotics in aquaculture. Therefore, an ideal substitution of antibiotics in aquaculture should be fully degradable to individual residues and thus lose antibacterial activity completely after degradation. $\mathrm{K}_{18} \mathrm{~S}_{4}$ was completely degraded within 6 hours in the presence of protease type XXIII from Aspergillus oryzae, as confirmed by NMR analysis on the disappearance of the characteristic peaks for $\alpha-\mathrm{CH}$ group on the peptide backbone at $4.27 \mathrm{ppm}$ and $3.82 \mathrm{ppm}$ (Fig 3f). The obtained mixture after 6 hours was analyzed by HRESI-MS and was identified as individual amino acid and dipeptide (Fig S16), which have no antibacterial activity, indicating that biodegradable $\mathrm{K}_{18} \mathrm{~S}_{4}$ can greatly reduce the antibacterial resistance and antimicrobial selective pressure in the environments (Fig 3g). In addition to enzymes produced by microorganisms, $\mathrm{K}_{18} \mathrm{~S}_{4}$ can also be degraded by trypsin and chymotrypsin that are widely distributed in the digestive tract. Depending on the enzyme for the treatment the degradation products were dipeptides or tripeptides, all of which have no antibacterial activity (Fig S17c-e). ع-Poly-L-lysine as a FDA approved antibacterial food additive showed slightly better antibacterial activity than $\mathrm{K}_{18} \mathrm{~S}_{4}$, but slower bacteria-killing (Fig S17a-b). Although $\varepsilon$-Poly-L-lysine was degradable by specific enzymes produced by few specific types of microorganisms ${ }^{53}$, it was highly stable in the presence of many common enzymes such as trypsin and chymotrypsin, and maintained the original antibacterial activity after treatment with trypsin and chymotrypsin (Fig S17c-d). Therefore, $\varepsilon$-Poly-L-lysine is not a suitable antibiotic substitute in aquaculture. 


\begin{tabular}{|c|c|c|c|c|c|c|c|c|}
\hline \multirow{2}{*}{ Antibacterial agents } & \multicolumn{8}{|c|}{ MIC (MBC), $\mu \mathrm{g} / \mathrm{mL}$} \\
\hline & S. aureus & E. coli & V. anguillarum & V. alginolyticus & V. parahemolyticus & V. cholerae & V. fluvialis & S.agalactiae \\
\hline $\mathrm{K}_{18} \mathrm{~S}_{4}$ & $\begin{array}{l}12.5 \\
(25)\end{array}$ & $\begin{array}{l}25 \\
(25)\end{array}$ & $\begin{array}{c}25 \\
(25)\end{array}$ & $\begin{array}{c}3.13 \\
(3.13)\end{array}$ & $\begin{array}{c}25 \\
(25)\end{array}$ & $\begin{array}{c}25 \\
(50)\end{array}$ & $\begin{array}{c}12.5 \\
(12.5)\end{array}$ & $\begin{array}{l}12.5 \\
(25)\end{array}$ \\
\hline $\begin{array}{l}\text { Thiamphenicol } \\
\text { (TAP) }\end{array}$ & $\begin{array}{c}6.25 \\
(>200)\end{array}$ & $\begin{array}{c}50 \\
(>200)\end{array}$ & $\begin{array}{c}0.78 \\
(3.13)\end{array}$ & $\begin{array}{l}12.5 \\
(25)\end{array}$ & $\begin{array}{l}3.13 \\
(6.25)\end{array}$ & $\begin{array}{c}6.25 \\
(6.25)\end{array}$ & $\begin{array}{l}6.25 \\
(25)\end{array}$ & $\begin{array}{c}12.5 \\
(50)\end{array}$ \\
\hline $\begin{array}{l}\text { Sulfadimethoxine } \\
\text { (SDM) }\end{array}$ & $\begin{array}{c}12.5 \\
(>200)\end{array}$ & $\begin{array}{c}50 \\
(>200)\end{array}$ & $\begin{array}{l}3.13 \\
(>200)\end{array}$ & $\begin{array}{l}>200 \\
(>200)\end{array}$ & $\begin{array}{c}6.25 \\
(>200)\end{array}$ & $\begin{array}{c}6.25 \\
(>200)\end{array}$ & $\begin{array}{l}>200 \\
(>200)\end{array}$ & $\begin{array}{l}>200 \\
(>200)\end{array}$ \\
\hline
\end{tabular}

b

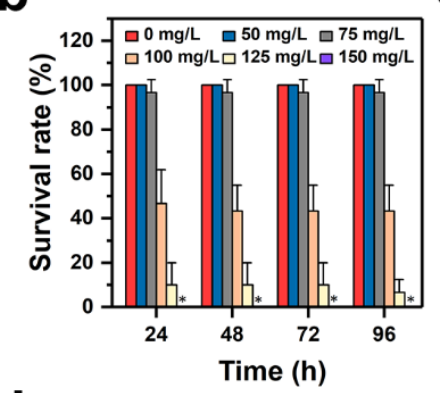

d

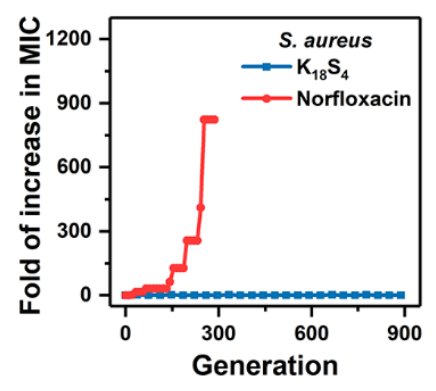

f
C
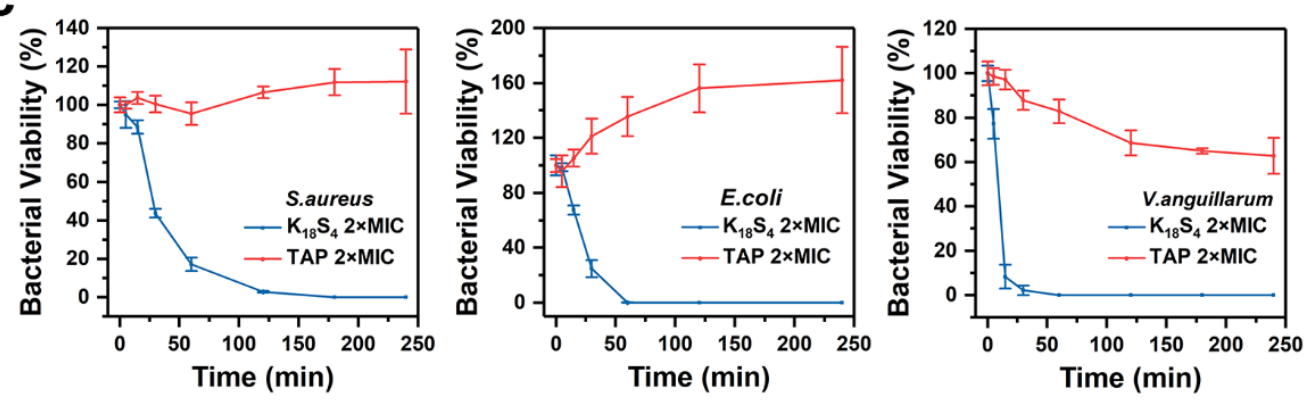

e
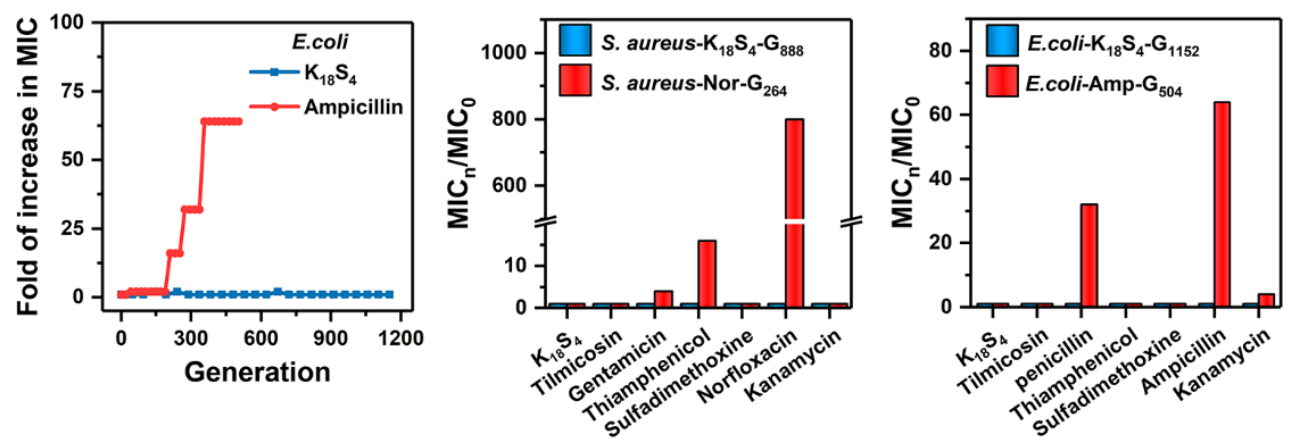

g
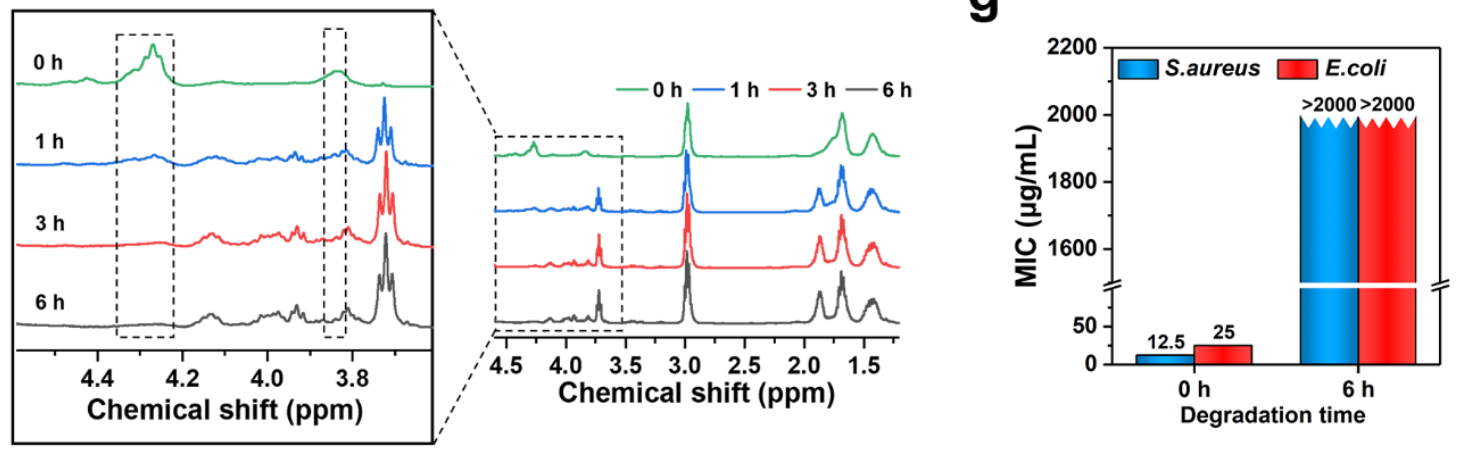

Fig 3. a) MIC and $\mathrm{MBC}$ values of $\mathrm{K}_{18} \mathrm{~S}_{4}$ and antibiotics against common pathogenic bacteria in aquaculture. MIC: the minimum inhibitory concentration, $\mathrm{MBC}$ : the minimum bactericidal concentration. b) Acute toxicity of $\mathrm{K}_{18} \mathrm{~S}_{4}$ on adult zebrafish, * means the survival rate is 0 . c) Killing kinetics of $\mathrm{K}_{18} \mathrm{~S}_{4}$ against $S$. aureus, E. coli and $V$. anguillarum at $2 \times$ MIC. d) Antimicrobial resistance assay on $S$. aureus and $E$. coli treated continuously with $\mathrm{K}_{18} \mathrm{~S}_{4}$ or antibiotics. e) The changes of MIC values for antibiotics against S. aureus- $\mathrm{K}_{18} \mathrm{~S}_{4}-\mathrm{G}_{888}$, S. aureus-norfloxacin$\mathrm{G}_{264}$, E. coli- $\mathrm{K}_{18} \mathrm{~S}_{4}-\mathrm{G}_{152}$ and E. coli-ampicillin- $\mathrm{G}_{504}$, which are treated with $\mathrm{K}_{18} \mathrm{~S}_{4}$ or norfloxacin for 888,264 , 1152 , and 504 generations, respectively, at $0.5 \times \mathrm{MBC}$. f) NMR spectrum of $\mathrm{K}_{18} \mathrm{~S}_{4}$ over time in the presence of protease XXIII from Aspergillus oryzae for biodegradability study. g) The MIC value change of $\mathrm{K}_{18} \mathrm{~S}_{4}$ before and after enzymatic degradation.

We also synthesized a morpholino naphthalimide fluorophore-tethered green fluorescent peptide polymer, 
Dye- $\mathrm{K}_{18} \mathrm{~S}_{4}$, for antimicrobial mechanism study using time-lapse fluorescent confocal imaging (Fig 4, Fig S8). After S. aureus was incubated with Dye- $\mathrm{K}_{18} \mathrm{~S}_{4}$ and propidium iodide (PI, red fluorescence) for around $450 \mathrm{~s}$, a small amount of Dye- $\mathrm{K}_{18} \mathrm{~S}_{4}$ began to accumulate in the cytoplasm without enrichment on the cell membrane beforehand (Fig 4b). At about 1260s, a burst of Dye- $\mathrm{K}_{18} \mathrm{~S}_{4}$ and PI into the cytoplasm indicated critical damages on the cell membrane of $S$. aureus (Fig $4 \mathrm{a}, 4 \mathrm{~b}$ ). The observed membrane damage was at the late stage of the bacteria-polymer interaction when $S$. aureus was killed by the peptide polymer. Since the Dye- $\mathrm{K}_{18} \mathrm{~S}_{4}$ was not enriched on the cell membrane, the membrane damage may not be caused by Dye- $\mathrm{K}_{18} \mathrm{~S}_{4}$ directly from the outside of the bacteria. Fluorescence intensity analysis across $S$. aureus cells, at 120s and 1500s after incubation, echoed above observation that Dye- $\mathrm{K}_{18} \mathrm{~S}_{4}$ did not enrich either on the cell membrane or in the cytoplasm at an early stage, but enriched inside the cell at a late stage (Figure 4c). Interestingly, incubation of E. coli and V. anguillurm with Dye- $\mathrm{K}_{18} \mathrm{~S}_{4}$ and PI both led to immediate enrichment of Dye- $\mathrm{K}_{18} \mathrm{~S}_{4}$ on the cell membrane, and then obvious enrichment of Dye- $\mathrm{K}_{18} \mathrm{~S}_{4}$ and PI into the bacteria after incubation for a longer time (Fig 4d, 4g). Fluorescence intensity analysis across $E$. coli and V. anguillurm, both echoed the two stages that Dye- $\mathrm{K}_{18} \mathrm{~S}_{4}$ firstly accumulated on the cell membrane of E. coli and V. anguillurm, and then entered the cells (Fig 4e-f, 4h-i). 
a
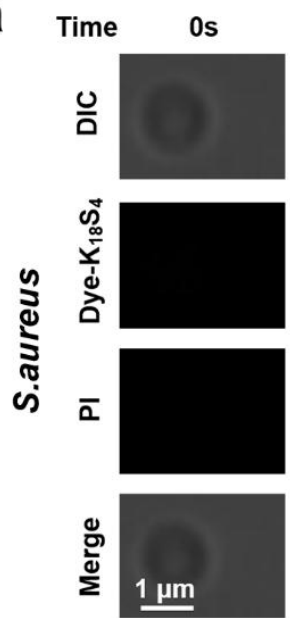

d

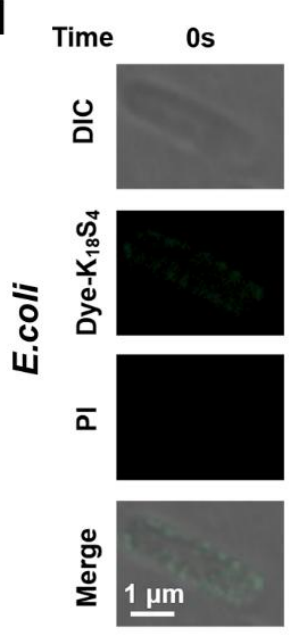

g

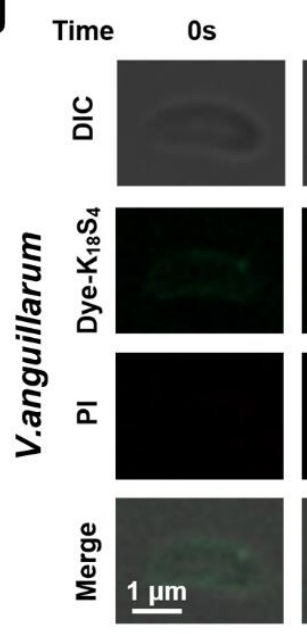

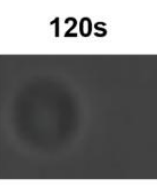
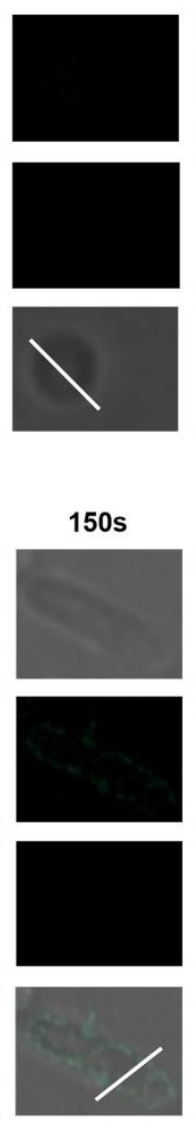

$120 s$
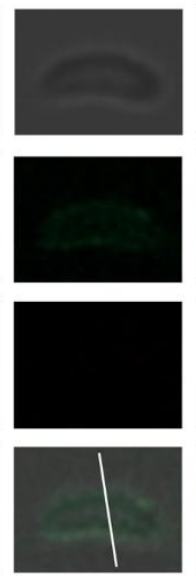
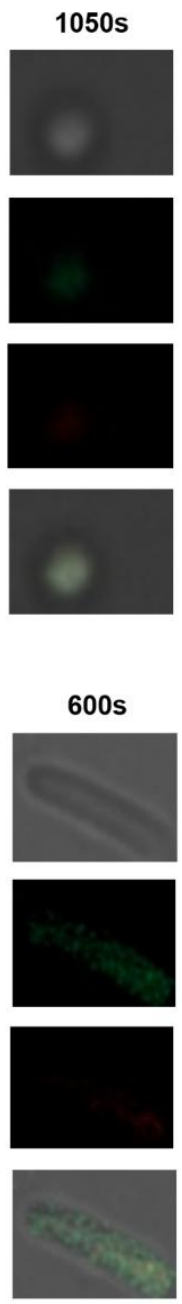

180s
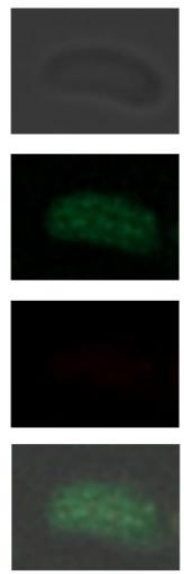
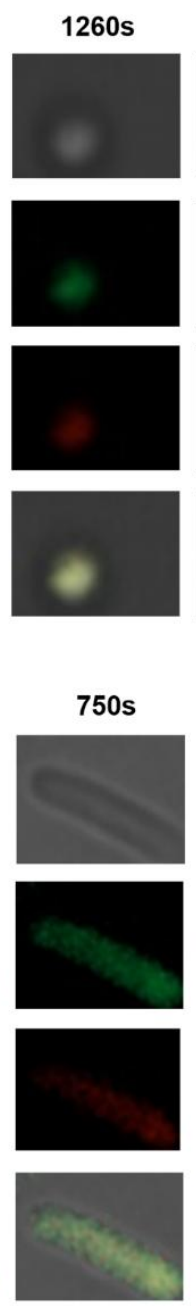

240s
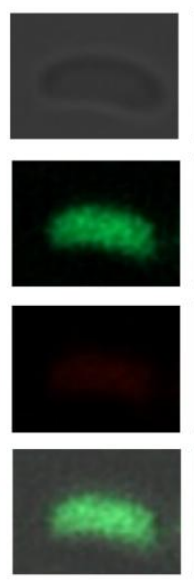

$1500 \mathrm{~s}$
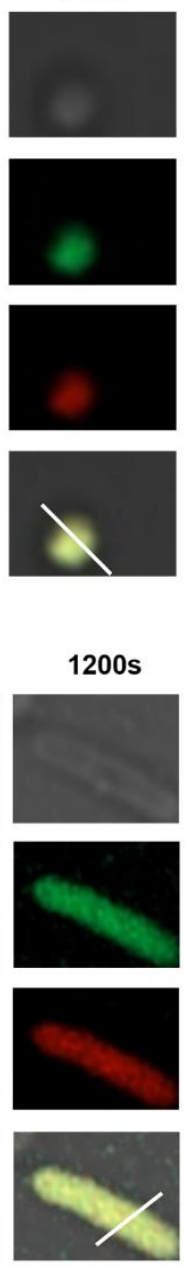

390 s
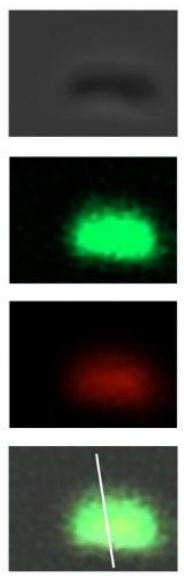

b

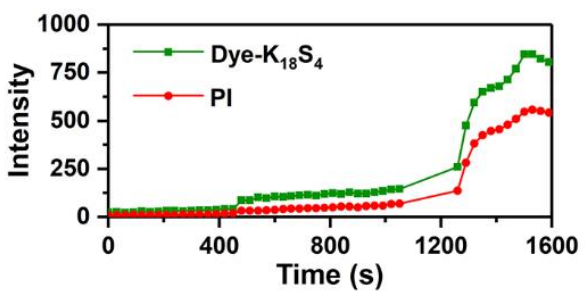

C

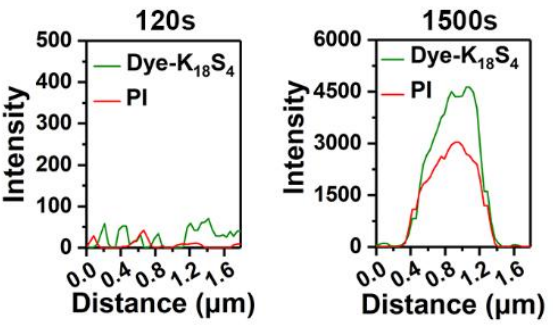

e

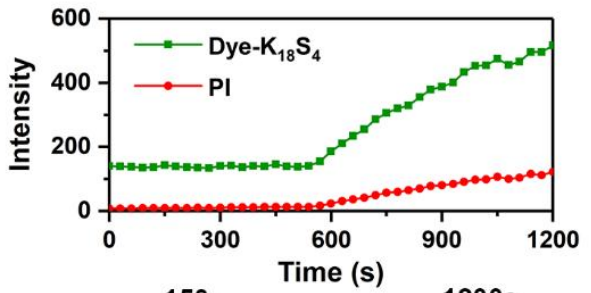

f

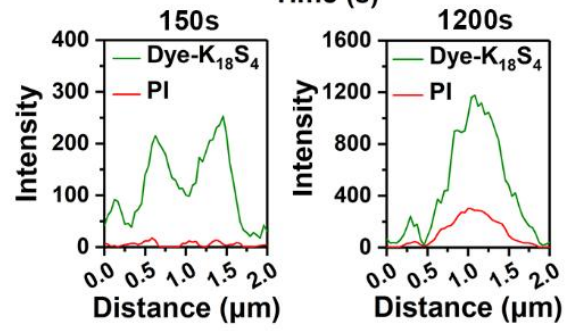

h
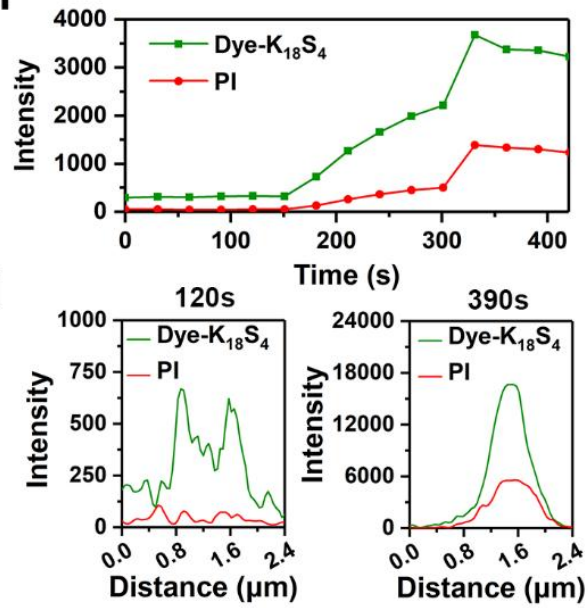

Fig 4. Time-lapse fluorescent confocal imaging of a) $S$. aureus, d) E. coli and g) V. anguillurm incubated with Dye- $\mathrm{K}_{18} \mathrm{~S}_{4}(5 \times \mathrm{MIC})$ in the presence of propidium iodide. Fluorescence intensity of Dye-K ${ }_{18} \mathrm{~S}_{4}$ and propidium iodide versus time in ROI (region of interest) of b) $S$. aureus, e) E. coli and h) V. anguillurm. Fluorescence intensity profiles of Dye- $\mathrm{K}_{18} \mathrm{~S}_{4}$ and propidium iodide across c) $S$. aureus at $120 \mathrm{~s}$ and $1556 \mathrm{~s}$, f) E. coli at $150 \mathrm{~s}$ and $1200 \mathrm{~s}$ and i) V. anguillurm at 120 s and $390 \mathrm{~s}$.

In further outer membrane permeability assays at the early stage of bacteria-polymer interaction, $\mathrm{K}_{18} \mathrm{~S}_{4}$ was 
found to cause significant permeability changes to the outer membranes of E. coli and V. anguillurm, similar to polymyxin B (Fig 5a, 5b). Adding exogenous LPS, a main component of the outer membrane, to $\mathrm{K}_{18} \mathrm{~S}_{4}$ showed a LPS dose-dependent antibacterial activity against E. coli and V. anguillurm (Fig 5c). These results are consistent to aforementioned observation of $\mathrm{K}_{18} \mathrm{~S}_{4}$ enrichment on the outer membrane of E. coli and V. anguillurm (Fig 4d, $4 \mathrm{~g}$ ). Therefore, the antibacterial mechanism of $\mathrm{K}_{18} \mathrm{~S}_{4}$ against Gram-negative E. coli and V. anguillurm may be explained by the strong interaction on cell membrane. Interestingly, $\mathrm{K}_{18} \mathrm{~S}_{4}$ only caused mild depolarization on cytoplasmic membrane of Gram-positive S. aureus (Fig 5d) at the early stage of bacteria-polymer interaction, which may not be enough to pose an adequate threat. So we speculated that there may still be other antibacterial mechanisms.

Oxidative stress is involved in the antibacterial process of a variety of cationic antibacterial peptides ${ }^{54,55}$. Membrane perturbation and DNA binding are both common ways to cause the increase of intracellular reactive oxygen species (ROS) level ${ }^{56}$. In addition to the observed mild membrane polarization at the early stage of bacteria-polymer interaction, $\mathrm{K}_{18} \mathrm{~S}_{4}$ could strongly bind to DNA at even low N:P ratio of 1:1, which suggests a possible generation of ROS within bacteria after $\mathrm{K}_{18} \mathrm{~S}_{4}$ treatment (Fig S18). So, we used 2,7dichlorodihydrofluorescein diacetate (DCFH-DA) as the probe to determine the ROS level in bacteria. After $\mathrm{K}_{18} \mathrm{~S}_{4}$ treatment on bacteria for 1 hour, the ROS level of S. aureus, E. coli and V. anguillurm all increased significantly compared to normal bacterial cells. (Fig 5e-g). By adding ROS scavenger N-acetyl-lcysteine (NAC) to inhibit the increase of ROS level in bacteria, the $\mathrm{MBC}$ of $\mathrm{K}_{18} \mathrm{~S}_{4}$ increased by only 2 times against E. coli and V. anguillurm, but 8 times (changing from $25 \mu \mathrm{g} / \mathrm{mL}$ to $200 \mu \mathrm{g} / \mathrm{mL}$ ) against $S$. aureus (Fig $5 \mathrm{~h}$ ). This result indicated that ROS played an important role in the antimicrobial process of $\mathrm{K}_{18} \mathrm{~S}_{4}$ against $S$. aureus. Among the possible ROS related antibacterial mechanisms, the increase of intracellular ROS level after the peptide polymer entered the bacteria could cause the damage of bacterial membrane due to membrane lipid peroxidation ${ }^{57,58}$. Characterization on the morphological changes of bacteria by transmission electron microscope (TEM) and scanning electron microscope (SEM) showed membrane lysis and cytoplasm outflow of S. aureus, E. coli and V. anguillurm after treatment with $\mathrm{K}_{18} \mathrm{~S}_{4}$ (Fig 5i, 5j). Altogether, although $\mathrm{K}_{18} \mathrm{~S}_{4}$ has a certain interaction with the cell membranes of Gram-positive and Gram-negative bacteria, the antimicrobial mechanisms of $\mathrm{K}_{18} \mathrm{~S}_{4}$ against Gram-positive and Gram-negative bacteria are different. We speculate that $\mathrm{K}_{18} \mathrm{~S}_{4}$ has a mild interaction with the bacterial membrane at the early stage of bacteria-polymer interaction during $\mathrm{K}_{18} \mathrm{~S}_{4}$ entering $S$. aureus; then membrane depolarization and subsequent strong interaction between $\mathrm{K}_{18} \mathrm{~S}_{4}$ and DNA induce an increase in intracellular ROS level, which cause the peroxidation of cell membrane and ultimately destruction of the bacterial membrane. For Gram-negative 
bacteria, we speculate that $\mathrm{K}_{18} \mathrm{~S}_{4}$ first binds with LPS to change the permeability of the outer membrane, and could stick between the outer membrane and the inner membrane before $\mathrm{K}_{18} \mathrm{~S}_{4}$ disrupts the bacterial membrane, similar to precedent reports on antibacterial peptides and their mimics ${ }^{59,60}$. Finally, the bacterial membrane is destroyed by the strong interaction between $\mathrm{K}_{18} \mathrm{~S}_{4}$ and bacterial membrane, resulting in death of Gram-negative bacteria.

a

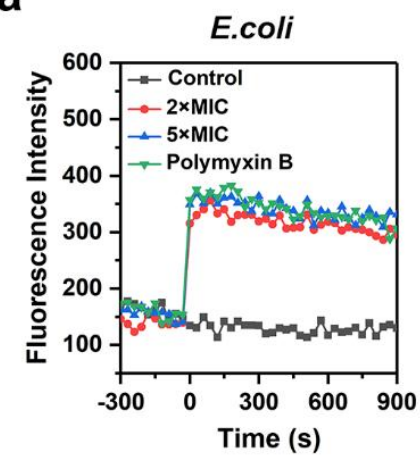

e

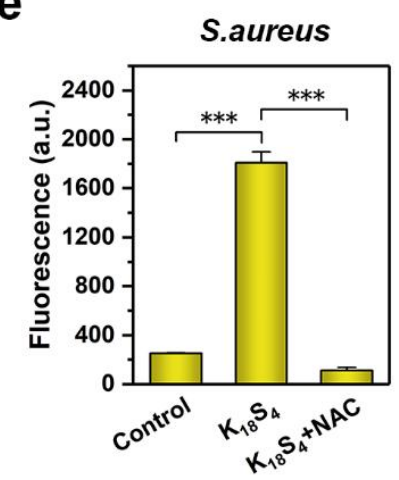

i

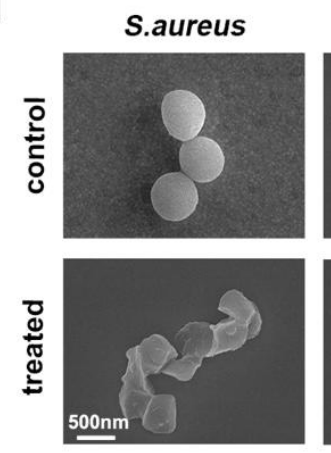

b

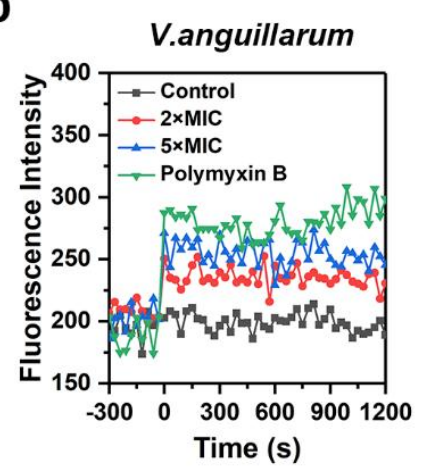

f

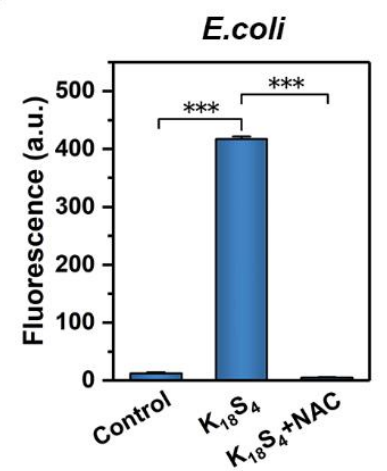

E.coli
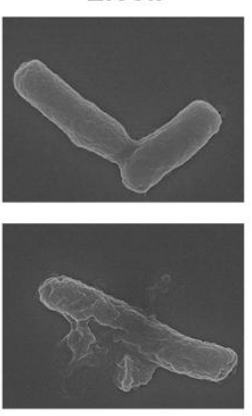
V.anguillarum

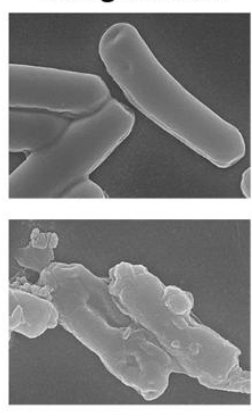

C

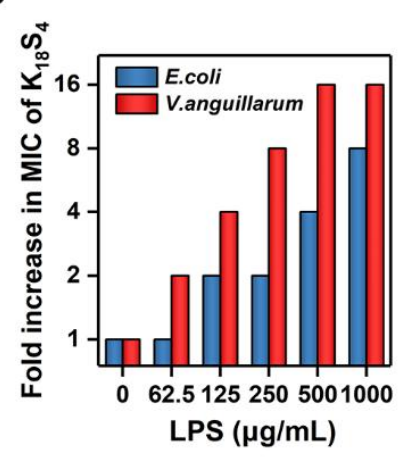

g

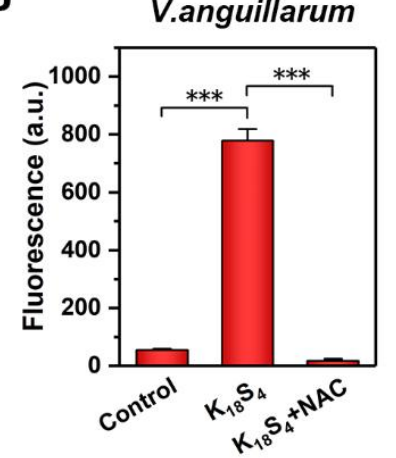

d

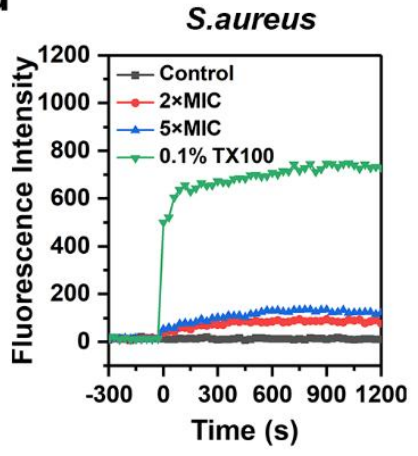

h

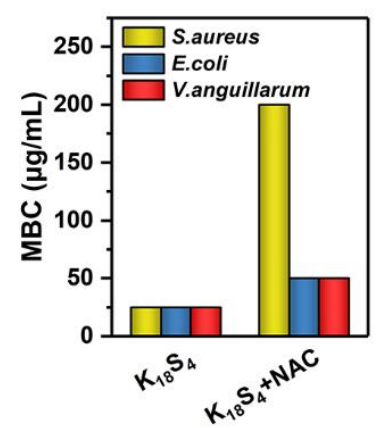

j

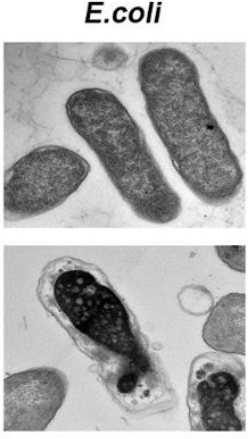

\section{V.anguillarum}
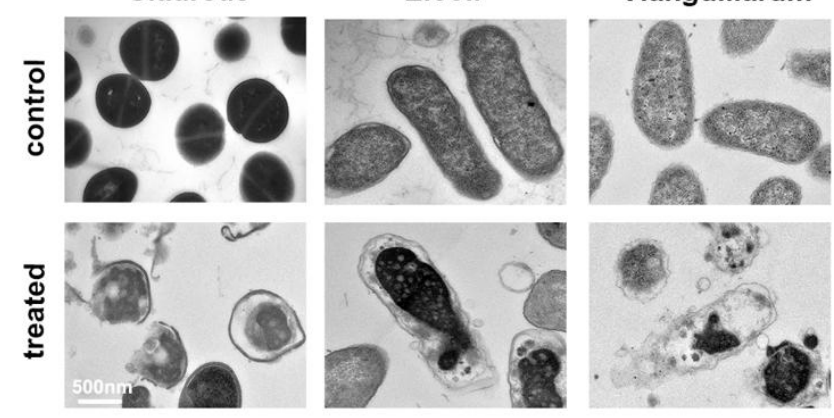

Fig 5. Outer membrane permeability of a) E. coli and b) V. anguillurm induced by $\mathrm{K}_{18} \mathrm{~S}_{4}$. c) Exogenous addition of purified LPS from $E$. coli inhibited the antibacterial activity of $\mathrm{K}_{18} \mathrm{~S}_{4}$ against Gram-negative bacteria $E$. coli and $V$. anguillurm in a dose-dependent manner. d) Cytoplasmic membrane depolarization of S. aureus induced by $\mathrm{K}_{18} \mathrm{~S}_{4}$. Intracellular ROS intensity produced by e) $S$. aureus, f) E. coli and g) V. anguillurm in the presence of PBS, $\mathrm{K}_{18} \mathrm{~S}_{4}(5 \times \mathrm{MIC})$, and the mixture of $\mathrm{K}_{18} \mathrm{~S}_{4}(5 \times \mathrm{MIC})$ and ROS quencher NAC (7.5 mM). *** p<0.001. h) The MBC values of $\mathrm{K}_{18} \mathrm{~S}_{4}$ against $S$. aureus, E. coli and $V$. anguillurm with or without NAC (7.5 mM). i) SEM and j) TEM characterization on $S$. aureus, E. coli and $V$. anguillurm with or without $\mathrm{K}_{18} \mathrm{~S}_{4}$ incubation. 
Encouraged by the potent and broad-spectrum in vitro antibacterial activity of $\mathrm{K}_{18} \mathrm{~S}_{4}$, we continued to evaluate the therapeutic potential of $\mathrm{K}_{18} \mathrm{~S}_{4}$ in vivo using an adult zebrafish infection model. Administration of antimicrobial agents by direct injection has proven as a rapid and effective method in aquaculture and has been recognized as a practical drug administration strategy ${ }^{61,62}$. So, zebrafish were intraperitoneally injected with V. anguillarum ( $4 \times 10^{6} \mathrm{CFU}$ (colony forming unit)), and a single dose of $\mathrm{K}_{18} \mathrm{~S}_{4}(20 \mathrm{mg} / \mathrm{kg})$ was administrated intraperitoneally at 30 minutes post infection. Then the survival rate of zebrafish was recorded every $12 \mathrm{~h}$ for 7 days (Fig 6a). Administration of $\mathrm{K}_{18} \mathrm{~S}_{4}$ increased the survival rate of infected zebrafish from $16.8 \%$ in the PBS-treated control group to $83.3 \%$ (Fig 6b). We also observed substantially reduced bacterial load in liver, spleen and kidney after administration of $\mathrm{K}_{18} \mathrm{~S}_{4}$ (Fig 6c). The infected zebrafish treated with PBS showed obvious symptoms of hemorrhagic sepsis; whereas, zebrafish treated with $\mathrm{K}_{18} \mathrm{~S}_{4}$ were similar to healthy zebrafish and showed no symptoms of hemorrhagic sepsis (Fig 6d). Furthermore, intraperitoneal administration of $\mathrm{K}_{18} \mathrm{~S}_{4}$ did not affect the liver and kidney function of healthy zebrafish (Fig 6e). These results altogether suggested that $\mathrm{K}_{18} \mathrm{~S}_{4}$ has promising therapeutic potential and favorable biosafety in vivo as potential antibacterial substitute of antibiotics in aquaculture. 
a
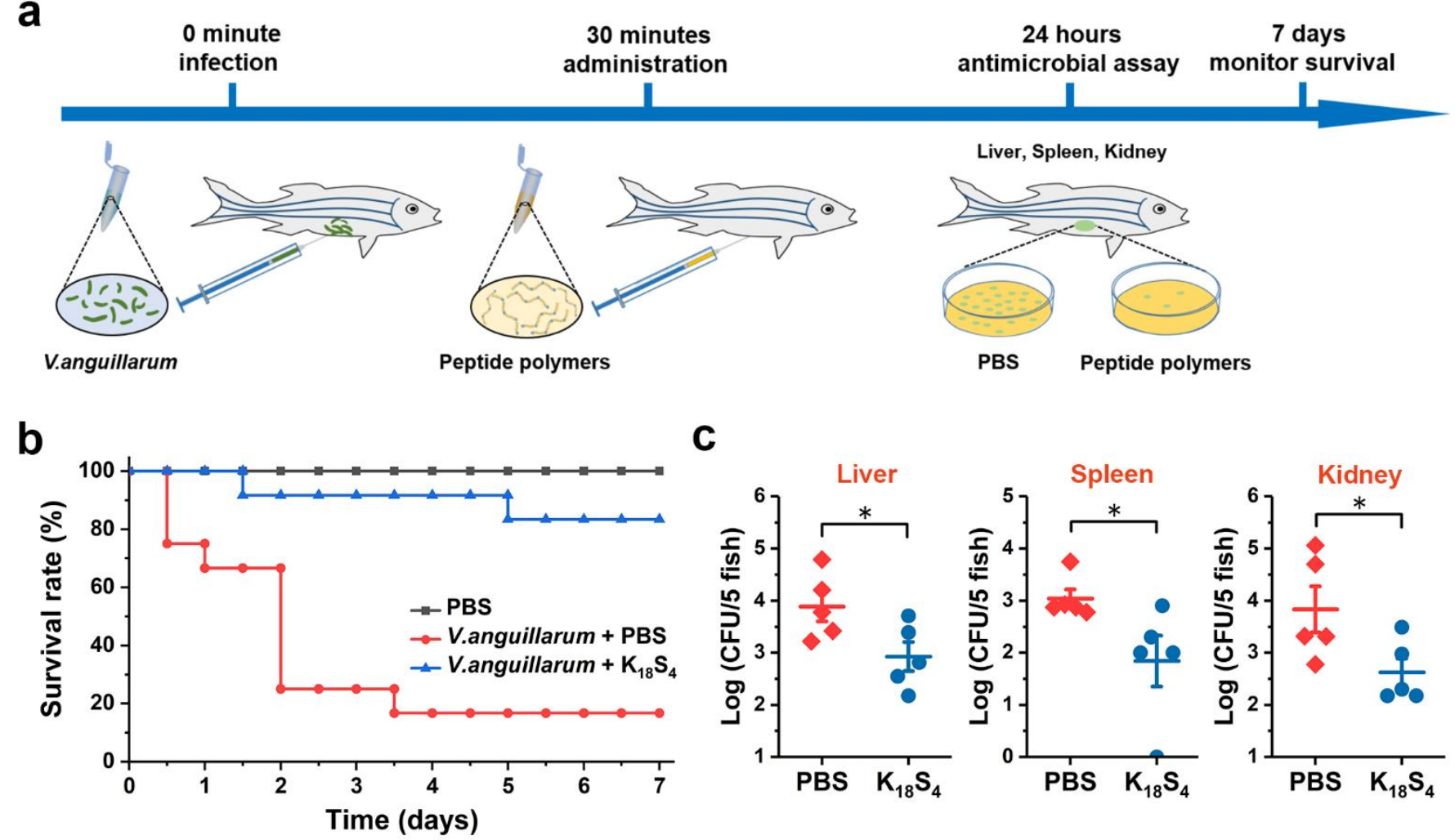

C

d

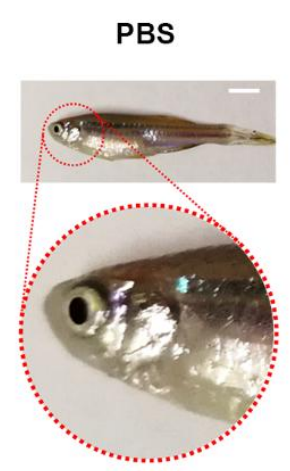

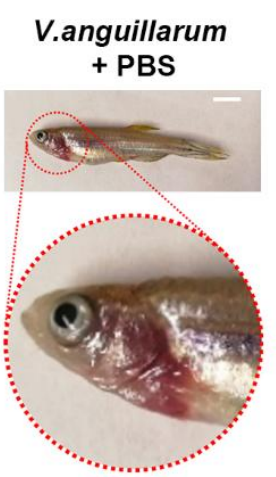
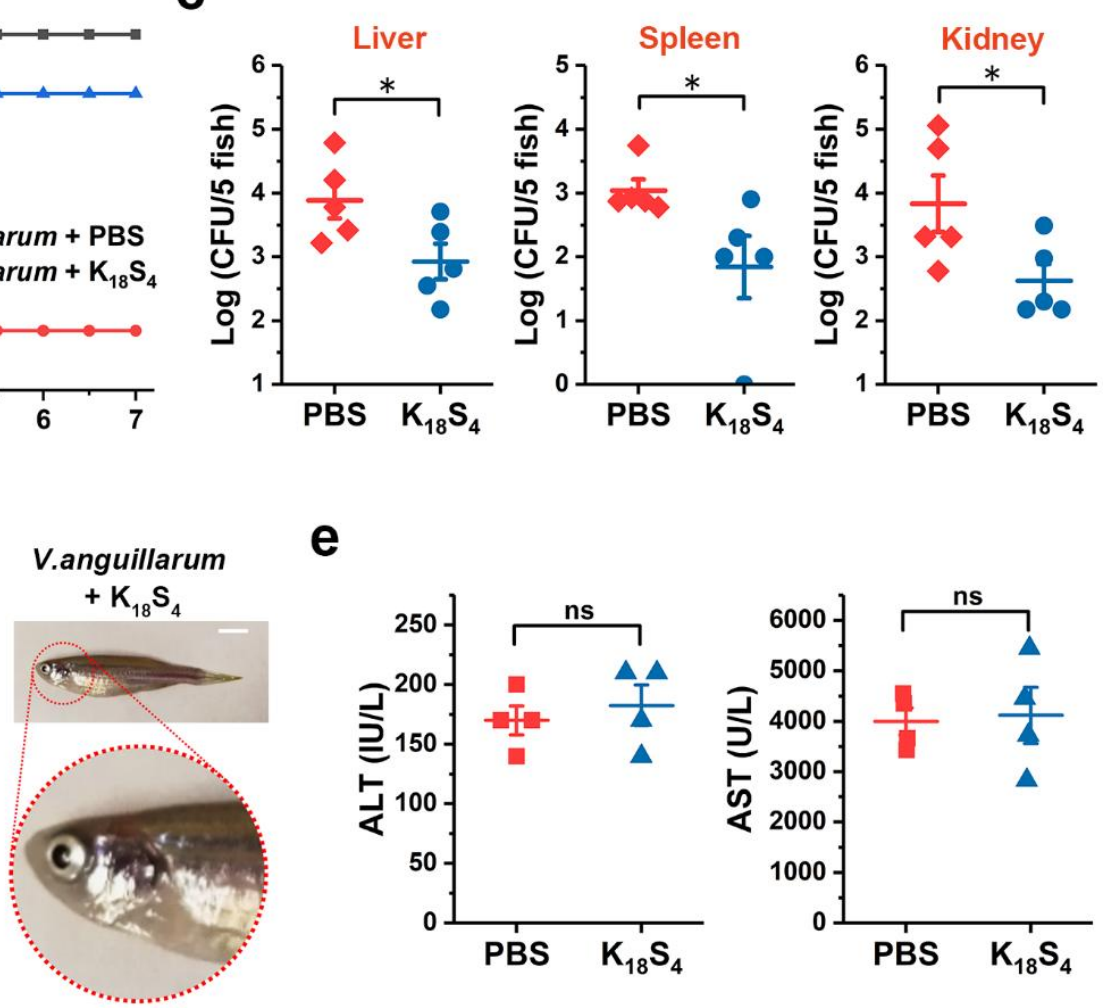

Fig 6. a) Schematic diagram of the in vivo anti-infectious study. b) Effect of $\mathrm{K}_{18} \mathrm{~S}_{4}$ on survival rate of zebrafish infected with $V$. anguillarum. c) Colony forming unit (CFU) of $V$. anguillarum in liver, spleen and kidney of zebrafish after treatment with PBS or $\mathrm{K}_{18} \mathrm{~S}_{4}$ for 24 hours. (*) represents $p<0.05$ (Student's t test). d) Symptoms of uninfected zebrafish, $V$. anguillarum-infected zebrafishes treated with PBS or $\mathrm{K}_{18} \mathrm{~S}_{4}$. Scale bar: $5 \mathrm{~mm}$. e) Serum biochemistry analysis of AST and ALT at 24 hours post-treatment with $\mathrm{K}_{18} \mathrm{~S}_{4}$ or PBS. Each data point was collected from blood of 10 fishes due to the limited amount of blood in each fish. ns (not significant) represents $p>0.05$.

\section{Discussion}

Finding antibiotic substitute in aquaculture is urgent and challenging. Promising substitute requires not only superior overall antibacterial performance but also complete degradability to ideally individual residues to totally lose antimicrobial activity and, therefore, cause no antimicrobial resistance and antimicrobial selective pressure. In this study, we prepared peptide polymers to explore their potential in addressing the long-lasting challenge of 
antimicrobial resistance and antimicrobial selective pressure and urgent need to replace the use of antibiotics in aquaculture. The optimal peptide polymer exhibits potent and broad-spectrum activity against common pathogenic bacteria in aquaculture and low cytotoxicity in vitro, as well as strong therapeutic potential in vivo. Moreover, bacteria didn't develop resistance to peptide polymers or cross resistance to antibiotics after bacteria were treated repeatedly with peptide polymers. The biodegradability of peptide polymers enabled their enzymatic degradation to single amino acids and dipeptides, which has no antibacterial activity and will not induce antimicrobial resistance and antimicrobial selective pressure. These results altogether suggest that peptide polymers are promising alternatives to antibiotics in aquaculture.

\section{Methods}

Synthesis of Ne-tert-butyloxycarbonyl-L-lysine NCA (Boc-L-Lys NCA) monomer: Boc-L-Lys NCA was prepared according to literature with slight modification ${ }^{63,64}$. Ne-tert-butyloxycarbonyl-L-lysine (10.0 g, 40.6 mmol) and $\alpha$-pinene $(16.6 \mathrm{~mL}, 107.4 \mathrm{mmol})$ were suspended in anhydrous THF $(0.3 \mathrm{M})$ in a round bottom flask cooled with an ice-water bath, followed by the addition of triphosgene $(5.4 \mathrm{~g}, 17.9 \mathrm{mmol})$ in anhydrous THF under $\mathrm{N}_{2}$. The reaction was stirred at $50{ }^{\circ} \mathrm{C}$ for 2 hours, and then concentrated to remove the solvent. The obtained mixture was dissolved in ethyl acetate $(80 \mathrm{~mL})$ and washed with ice water $(3 \times 80 \mathrm{~mL})$ and cold brine $(1 \times 80 \mathrm{~mL})$.

The collected organic layer was dried over anhydrous $\mathrm{MgSO}_{4}$, filtered and concentrated to give a crude product. The crude product was purified from recrystallization for three times using mixed solvent of ethyl acetate/hexane $(1 / 2, \mathrm{v} / \mathrm{v})$ in a glovebox with $\mathrm{N}_{2}$ protection to afford pure NCA monomer as a white solid (3.9 g, 35.3\%). ${ }^{1} \mathrm{H}$ NMR (400 MHz, $\left.\mathrm{CDCl}_{3}\right): \delta 6.92$ (br, 1H), 4.66 (br, 1H), 4.33 (dd, J = 6.4, $\left.4.4 \mathrm{~Hz}, 1 \mathrm{H}\right), 3.14$ (s, 2H), 1.99-2.05 (m, 1H), $1.80-1.89(\mathrm{~m}, 1 \mathrm{H}), 1.5-1.56(\mathrm{~m}, 4 \mathrm{H}), 1.45(\mathrm{~s}, 9 \mathrm{H})$.

Synthesis of O-(tert-butyl)-L-serine NCA ( $t$ Bu-L-Ser NCA) monomer: $t$ Bu-L-serine NCA ${ }^{65}$ was prepared from O-(tert-butyl)-L-serine ( $5 \mathrm{~g}, 31 \mathrm{mmol})$, by using the similar method as the Boc-L-lysine NCA, to give a white solid (3.8 g, 65.5\%). ${ }^{1} \mathrm{H}$ NMR (400 MHz, $\left.\mathrm{CDCl}_{3}\right): \delta 6.53$ (br, $\left.1 \mathrm{H}\right), 4.42$ (dd, $\left.J=4,2.4 \mathrm{~Hz}, 1 \mathrm{H}\right), 3.72-3.66$ $(\mathrm{m}, 2 \mathrm{H}), 1.17(\mathrm{~s}, 9 \mathrm{H})$.

Synthesis of peptide polymers: The synthesis of $\mathrm{K}_{18} \mathrm{~S}_{4}$ was described below and other peptide polymers were synthesized in a similar way. The polymerization was carried out in a nitrogen purged glovebox. Firstly, Boc-LLys NCA (108.9 mg, $0.4 \mathrm{mmol})$ and $t$ Bu-L-Ser NCA (18.7 mg, $0.1 \mathrm{mmol})$ were dissolved in anhydrous THF (7 $\mathrm{mL}$ ) in a dried reaction vial equipped with a magnetic stir bar. Then a solution of LiHMDS (16.7 mg, $0.1 \mathrm{mmol})$ in anhydrous THF $(1 \mathrm{~mL})$ was added to the reaction and the reaction was stirred at room temperature for 5 minutes. After the completion of the polymerization, the reaction solution was poured into $80 \mathrm{~mL}$ hexane to precipitate out 
a white flocculent solid. The solid was then collected from centrifugation, dissolved in THF (1 mL), and precipitated our again using hexane $(80 \mathrm{~mL})$. This cycle was repeated for three times to obtain the side-chain protected peptide polymers. Polymers at the side-chain protected stage were characterized by GPC using DMF as the mobile phase. N-Boc and tert-butyl protecting groups were removed by incubating polymers in $2 \mathrm{~mL}$ trifluoroacetic acid (TFA) for 2 hours under gentle shaking. Removing TFA gave a yellow oil, which was dissolved in methanol $(1 \mathrm{~mL})$ and then precipitated out as a white flocculent solid by adding methyl tert-butyl ether $(40 \mathrm{~mL})$ to the mixture. The deprotected peptide polymers were collected by centrifugation. After three cycles of dissolution/precipitation, the collected white precipitate was dissolved in deionized water and lyophilized to obtain the final peptide polymers for subsequent research.

Synthesis of N-terminal functionalized peptide polymers: The chain length of peptide polymers can be further determined by $\mathrm{N}$-terminal functionalization ${ }^{51}$. After completion of the reaction for normal peptide polymer synthesis, tert-butyl benzylamine ( 5 equiv. of initiator) was added into the reaction mixture and the reaction was stirred for 12 hours. N-terminal functionalized peptide polymers were obtained according to the above purification and deprotection operation. All deprotected N-terminal functionalized peptide polymers were characterized by ${ }^{1} \mathrm{H}$ NMR.

Synthesis of Dye-K18S4: 2-(3-aminopropyl)-6-morpholino-1H-benzo[de]isoquinoline-1,3(2H)-dione was synthesized as described in the previous literature ${ }^{66,67}$. The synthesis of Dye- $\mathrm{K}_{18} \mathrm{~S}_{4}$ was similar to the N-terminal functionalized peptide polymers except that tert-butyl benzylamine was replaced with 2-(3-aminopropyl)-6morpholino-1H-benzo[de]isoquinoline-1,3(2H)-dione $(5$ equiv. of initiator $)$ during the $\mathrm{N}$-terminal functionalization process. And Dye- $\mathrm{K}_{18} \mathrm{~S}_{4}$ was obtained according to the above purification and deprotection operation. The deprotected Dye- $\mathrm{K}_{18} \mathrm{~S}_{4}$ was characterized by ${ }^{1} \mathrm{H}$ NMR.

Microorganisms and culture: All strains were from American Type Culture Collection (ATCC), China Center of Industrial Culture Collection (CICC), China General Microbiological Culture Collection Center (CGMCC) and China Veterinary Culture Collection Center (CVCC), respectively. Staphylococcus aureus ATCC6538, Escherichia coli ATCC25922, Pseudomonas aeruginosa ATCC9027, Vibrio alginolyticus CICC10484, Vibrio chlolerae CICC23794, Streptococcus agalactiae CICC10465, Mannheimia haemolytica CVCC3832, Streptococcus suis CVCC3311, Salmonella choleraesuis CVCC2139, Salmonella pullorum CVCC1879, Salmonella anatum CICC21498 and Salmonella typhimurium CVCC2220 were cultured at $37{ }^{\circ} \mathrm{C}$. Vibrio anguillarum CICC24712, Vibrio parahaemolyticus CGMCC1.1616, Vibrio fluvialis CICC21612 were cultured at $30{ }^{\circ} \mathrm{C}$. Vibrio was cultured in $2216 \mathrm{E}$ medium and other strains were cultured in Luria-Bertani (LB) broth.

\section{Minimum Inhibitory Concentration (MIC) and Minimum Bactericidal Concentration (MBC)}

Measurement: The definition of MIC is the lowest concentration of an antimicrobial agent that completely inhibits the growth of microorganisms. The MIC was measured using a standard serial microdilution method. 
Briefly, $50 \mu \mathrm{L}$ of antimicrobial agent solution in $\mathrm{MH}$ medium was added in each well of a 96-well plate. Overnight cultured bacteria were washed and diluted in MH medium to a cell density at $2 \times 10^{5} \mathrm{CFU} / \mathrm{mL}$. Then $50 \mu \mathrm{L}$ of the suspension was added into each well. The final concentration of the peptide polymers in the 96-well plate was in the range of 3.13-200 $\mu \mathrm{g} / \mathrm{mL}$. MH medium only and bacteria in $\mathrm{MH}$ medium were used as the blank control and the positive control, respectively, in the same 96 -well plate. The 96 -well plate was incubated at $37^{\circ} \mathrm{C}$ or $30^{\circ} \mathrm{C}$ for 9 hours, and the absorbance at $600 \mathrm{~nm}$ was measured on a Molecular Devices SpectraMax M2 precision microplate reader. The percentage of bacteria cell growth was calculated from

$$
\% \text { cell growth }=\frac{A_{600}^{\text {sample }}-A_{600}^{\text {blank }}}{A_{600}^{\text {control }}-A_{600}^{\text {blank }}} \times 100
$$

The experiment was repeated three times independently.

The definition of $\mathrm{MBC}$ is the minimum drug concentration required to kill $99.9 \%$ of the tested microorganisms. After finishing the MIC measurement, $2 \mu \mathrm{L}$ of bacteria suspension from each well in the 96-well plate was transferred to an agar plate. Then the agar plate was incubated for 18 hours and the CFU was counted by naked eyes to determine the MBC values.

Hemolysis activity: The hemolytic activity was measured using human red blood cells. The blood was washed with Tris-buffered saline (TBS, pH=7.2) three times to get red blood cells (RBCs), and RBCs were resuspended in TBS to achieve 5\% (v/v). Serial dilution of peptide polymer solution was done in a 96-well plate like in MIC operation. TBS was used as a blank control, and Triton X-100 (0.1\% v/v in TBS) was used as the positive control. After adding $50 \mu \mathrm{L}$ RBC suspension, the 96 -well plate was incubated at $37^{\circ} \mathrm{C}$ for 1 hour. Subsequently, the plate was centrifuged at $3700 \mathrm{rpm}$ for 5 minutes and $80 \mu \mathrm{L}$ of the supernatant was transferred into another 96-well plate. The absorbance of supernatant was determined at $405 \mathrm{~nm}$ using a microplate reader. The experiment was repeated three times independently. The percentage of hemolysis was calculated from

$$
\% \text { Hemolysis }=\frac{A_{405}^{\text {sample }}-A_{405}^{\text {blank }}}{A_{405}^{\text {control }}-A_{405}^{\text {blank }}} \times 100
$$

Cytotoxicity assay: The cytotoxicity of peptide polymers was performed according to literature ${ }^{68}$. Firstly, COS7 was cultured in Dulbecco's modified Eagle's medium (DMEM) at $37^{\circ} \mathrm{C}$ and $5 \% \mathrm{CO}_{2}$ to the appropriate density. After cells were diluted to 5000 cells $/ \mathrm{mL}, 100 \mu \mathrm{L}$ of cell suspension was added to each well of a 96-well plate and the plate was incubated at $37^{\circ} \mathrm{C}$ for 24 hours. After removing the old medium from each well, $100 \mu \mathrm{L}$ DMEM containing peptide polymers was added to each well by a 2 -fold dilution method to obtain a concentration in the range of $6.25-200 \mu \mathrm{g} / \mathrm{mL}$. After incubation for 24 hours, $10 \mu \mathrm{L}$ of MTT solution $(5 \mathrm{mg} / \mathrm{mL})$ was added to each well, followed by incubating the plate in the dark for another 4 hours. After removing the suspension from each well, $150 \mu \mathrm{L}$ of DMSO was added to each well, and the plate was shaken in a shaker for 20 minutes to fully dissolve the purple solid. The absorbance at $570 \mathrm{~nm}$ was recorded using a Molecular Devices SpectraMax M2 precision microplate reader. DMEM medium only and DMEM medium containing growing cells were used as 
the blank and positive controls, respectively. The experiment was repeated three times independently. The percentage of cell viability was calculated from

$$
\% \text { cell viability }=\frac{A_{570}^{\text {sample }}-A_{570}^{\text {blank }}}{A_{570}^{\text {control }}-A_{570}^{\text {blank }}} \times 100
$$

Bacteria killing kinetics: $S$. aureus, E. coli and V. anguillarum cultured to the stationary phase were diluted with $\mathrm{MH}$ medium to a concentration of $2 \times 10^{5} \mathrm{CFU} / \mathrm{mL}$ for use. The suspension was mixed with $\mathrm{K}_{18} \mathrm{~S}_{4}$ or thiamphenicol solution in an equal volume at a final concentration of $2 \times \mathrm{MIC}$, and then the mixture was incubated at $37^{\circ} \mathrm{C}$ or $30{ }^{\circ} \mathrm{C}$. An aliquot of $20 \mu \mathrm{L}$ of the bacteria suspension was taken out at $0,10,30,60,120,240$ minutes during the incubation and diluted to a suitable bacterial concentration and then spread on an agar plate. Finally, the agar plates were incubated at $37{ }^{\circ} \mathrm{C}$ or $30{ }^{\circ} \mathrm{C}$ for 18 hours, and the percentage of survival colonies at different time points can be calculated after counting CFU.

Drug resistance test: $S$. aureus, and $E$. coli cultured to the stationary phase were diluted with $\mathrm{MH}$ medium to a concentration of $2 \times 10^{5} \mathrm{CFU} / \mathrm{mL}$ for use. $\mathrm{K}_{18} \mathrm{~S}_{4}$ or antibiotic was added to the bacteria suspension to a final concentration of $0.5 \times \mathrm{MBC}$. The resulting mixture was incubated at $37^{\circ} \mathrm{C}$ for 24 hours under shaking at $200 \mathrm{rpm}$. Then the suspension was diluted 400 times with $\mathrm{MH}$ medium again, and another round of co-cultivation of antibacterial agent with bacteria was carried out. The cycle was repeated every 24 hours and the change of MIC and MBC value was detected every 4 days. The concentration of $\mathrm{K}_{18} \mathrm{~S}_{4}$ and antibiotics was adjusted and maintained at $0.5 \times \mathrm{MBC}$ according to test results. The growth generation of bacteria treated with $\mathrm{K}_{18} \mathrm{~S}_{4}$ or antibiotic was calculated according to the following bacterial growth kinetics.

Bacterial growth kinetics: $S$. aureus and E. coli cultured to the exponential period were diluted with MH medium to a concentration of $2 \times 10^{5} \mathrm{CFU} / \mathrm{mL}$. Then the working suspension was treated with $\mathrm{K}_{18} \mathrm{~S}_{4}$ or antibiotic at a final concentration of $0.5 \times \mathrm{MBC}$ and the mixture was cultured at $37{ }^{\circ} \mathrm{C}$ under gentle shaking. During the cultivation process, $10 \mu \mathrm{L}$ of the mixture was taken out each time and streaked on the agar plate at different time points. Then the agar plates were cultured at $37^{\circ} \mathrm{C}$ for 18 hours. Finally, the bacterial growth rate can be calculated by counting the CFU on the agar plate.

Enzymatic biodegradation: The peptide polymer $(4 \mathrm{mg} / \mathrm{mL})$ was mixed with protease $(0.2 \mathrm{mg} / \mathrm{mL}$ protease XXIII from Aspergillus oryzae, or $0.1 \mathrm{mg} / \mathrm{mL}$ trypsin, or $0.1 \mathrm{mg} / \mathrm{mL}$ chymotrypsin) in PBS $(0.01 \mathrm{M}, \mathrm{pH}=6.5$ for protease XXIII, $\mathrm{pH}=7.2$ for trypsin and chymotrypsin) and the mixture was incubated at $37{ }^{\circ} \mathrm{C}$ (for trypsin and chymotrypsin) or $45^{\circ} \mathrm{C}$ (for protease XXIII), respectively. Aliquots were taken out at time intervals and heated at $100{ }^{\circ} \mathrm{C}$ for 10 minutes to inactivate the enzyme. Then the MIC of degradation solution was measured. The 
degradation products were characterized by NMR to determine the time required for full degradation. The components of the final degradation products were determined by ESI-MS.

Scanning electron microscopy (SEM) imaging: S. aureus, E. coli and V. anguillarum cultured to the exponential period were diluted with $\mathrm{MH}$ medium to a concentration of $2 \times 10^{7} \mathrm{CFU} / \mathrm{mL}$. Then the bacteria suspension was mixed with an equal volume of $\mathrm{K}_{18} \mathrm{~S}_{4}$ solution, and the final polymer concentration was $5 \times \mathrm{MIC}$. The mixture was cultured in an incubator for a period of time until approximately $90 \%$ of the bacteria died. After centrifugation at $4000 \mathrm{rpm}$ for 5 minutes, the supernatant was carefully discarded, and the remained bacteria were mixed well by adding $1 \mathrm{~mL}$ PBS. The bacteria were collected again by centrifugation. Then $1 \mathrm{~mL}$ PBS buffer containing 4\% glutaraldehyde was added, and the sample was fixed overnight at room temperature. After centrifugation, the supernatant was removed and the collection was washed with $1 \mathrm{~mL}$ PBS, followed by gradual dehydration with different concentrations of ethanol $(30,50,70,80,90,95$ and 100\%). The dehydrated bacteria were dispersed in $20 \mu \mathrm{L}$ anhydrous ethanol and pipetted onto a gold-plated silicon wafer for observation by SEM.

Transmission electron microscope (TEM) imaging: The preparation of samples is similar to SEM characterization. S. aureus, E. coli and $V$. anguillarum treated with $\mathrm{K}_{18} \mathrm{~S}_{4}(5 \times \mathrm{MIC})$ were collected by centrifugation and fixed overnight with $2.5 \%$ glutaraldehyde. After being washed with PBS for three times, $S$. aureus, E. coli and V. anguillarum were fixed with $1 \% \mathrm{OsO}_{4}$ in $\mathrm{PBS}$ for 1.5 hours. Then samples were washed two times with PBS and dehydrated with a series of graded ethanol solutions (30\% - 100\%). The embedding liquid and acetone were mixed at a ratio of $1: 1$ and 3:1 (v/v) to treat the dehydrated sample for 1 hour, respectively. Then samples were treated with pure embedding liquid overnight and slices with a thickness of 70-90 nm were obtained with LEICA EM UC7 ultra-thin microtome. Finally, the slices were stained with $2 \%$ uranyl acetate and lead citrate for 10 minutes and observed by transmission electron microscope.

Time-lapse fluorescent confocal imaging: S. aureus, E. coli and V. anguillarum cultured to the exponential period were diluted with $\mathrm{MH}$ medium to a concentration of $2 \times 10^{7} \mathrm{CFU} / \mathrm{mL}$. Then $10 \mu \mathrm{L}$ of this suspension was dropped on the dish with glass bottom. After standing for 5 minutes, Dye- $\mathrm{K}_{18} \mathrm{~S}_{4}(10 \times \mathrm{MIC})$ and PI $(40 \mu \mathrm{M})$ was mixed in a ratio of $1 / 1(\mathrm{v} / \mathrm{v})$ and $10 \mu \mathrm{L}$ of the mixture was dropped into the bacteria solution. Finally, three channels were selected in the confocal microscope, the bright field of differential interference contrast (DIC), 488 nm (detecting Dye- $\mathrm{K}_{18} \mathrm{~S}_{4}$ ) and $562 \mathrm{~nm}$ (detecting PI), and images were collected at 30s intervals.

Outer membrane permeability studies: E. coli and V. anguillarum cultured to the exponential period were washed three times with HEPES buffer $(5 \mathrm{mM}, \mathrm{pH}=7.4$, containing $5 \mathrm{mM}$ glucose $)$ and diluted to $10^{7} \mathrm{CFU} / \mathrm{mL}$. 
Then the bacteria suspension were incubated with the membrane potential-sensitive fluorescent dye 1-NPhenylnaphthylamine $(10 \mu \mathrm{M})$, and the fluorescence value at an excitation wavelength of $350 \mathrm{~nm}$ and an emission wavelength of $420 \mathrm{~nm}$ was recorded by SpectraMax ${ }^{\circledR M} 2$ plate reader until it was stable. Finally, $\mathrm{K}_{18} \mathrm{~S}_{4}$ was added at the final concentration of $2 \times \mathrm{MIC}$ and $5 \times \mathrm{MIC}$, and the fluorescence value was recorded using polymyxin B as positive control.

LPS binding assays: $E$. coli and $V$. anguillarum cultured to the stationary phase were diluted with MH medium to $2 \times 10^{5} \mathrm{CFU} / \mathrm{mL}$. A two-fold dilution of $\mathrm{K}_{18} \mathrm{~S}_{4}$ was prepared in a 96-well plate with $\mathrm{MH}$ medium containing different concentrations of LPS $(0-2000 \mu \mathrm{g} / \mathrm{mL})$ purified from $E$. coli. Then $50 \mu \mathrm{L}$ of the bacteria suspension was added to mix with the $50 \mu \mathrm{L}$ of the peptide polymers-LPS solution. MIC values were obtained after the 96-well plate was incubated for 9 hours.

Cytoplasmic membrane depolarization studies: $S$. aureus cultured to the stationary phase was washed three times with HEPES buffer ( $5 \mathrm{mM}, \mathrm{pH}=7.4$, containing $20 \mathrm{mM}$ glucose) and diluted to $10^{7} \mathrm{CFU} / \mathrm{mL}$. Then the bacteria suspension was incubated with the membrane potential-sensitive fluorescent dye 3,3'Dipropylthiadicarbocyanine Iodide $(0.8 \mu \mathrm{M})$ for 1 hour until the dye was incorporated into the cell membrane. After adding $\mathrm{KCl}(0.1 \mathrm{M})$ to balance the charge inside and outside of the cytoplasm, the fluorescence value at an excitation wavelength of $622 \mathrm{~nm}$ and an emission wavelength of $670 \mathrm{~nm}$ was recorded by SpectraMax ${ }^{\circledR}$ M2 plate reader until it was stable. Finally, $\mathrm{K}_{18} \mathrm{~S}_{4}$ was added at the final concentration of $2 \times \mathrm{MIC}$ and $5 \times \mathrm{MIC}$, and the fluorescence value was recorded with Triton X-100 as the positive control.

Intracellular ROS assay: S. aureus, E. coli and V. anguillarum cultured to the stationary phase were washed three times with PBS. Then the bacteria were resuspended in PBS to $2 \times 10^{8} \mathrm{CFU} / \mathrm{mL}$ for $S$. aureus and $2 \times 10^{7}$ $\mathrm{CFU} / \mathrm{mL}$ for $E$. coli and $V$. anguillarum. The bacteria suspension was then mixed with the solution of ROS sensitive fluorescent probe DCFH-DA $\left(40 \mu \mathrm{M}\right.$ in PBS) at a ratio of $1 / 1(\mathrm{v} / \mathrm{v})$. The mixture was incubated at $37^{\circ} \mathrm{C}$ or $30{ }^{\circ} \mathrm{C}$ for 30 minutes, and then the bacteria were harvested by centrifugation and washed with PBS for three times to remove the extracellular DCFH-DA. An aliquot of $90 \mu \mathrm{L}$ of bacteria suspension was placed in a $384-$ well plate, and then $10 \mu \mathrm{L}$ of $\mathrm{K}_{18} \mathrm{~S}_{4}, \mathrm{~K}_{18} \mathrm{~S}_{4}+\mathrm{NAC}(7.5 \mathrm{mM})$ or PBS was added, respectively. The 2',7'Dichlorofluorescein (DCF) fluorescence intensity at an excitation wavelength of $488 \mathrm{~nm}$ and an emission wavelength of $530 \mathrm{~nm}$ was recorded by SpectraMax® M2 plate reader.

DNA binding assay: Agarose gel electrophoresis was used to evaluate the ability of $\mathrm{K}_{18} \mathrm{~S}_{4}$ to bind with DNA. According to the different N/P ratio $(0,0.5,1,2$ and 3 , respectively), $5 \mu \mathrm{L}$ of different concentration gradient 
polymers were added to $5 \mu \mathrm{L}$ DNA solution $(140 \mu \mathrm{g} / \mathrm{mL})$ and incubated for 30 minutes at room temperature. Here $\mathrm{N}$ represents the amino group of the polymer side chain, and P represents the phosphate ion in DNA. The resulting samples mixed with ethidium bromide in Tris-borate-EDTA buffer and analyzed by electrophoresis using $1 \%$ agarose gel at $120 \mathrm{~V}$ for 30 minutes. DNA bands were visualized using a Gel Documentation and Image Analysis System (SAGECREATION, China).

Acute toxicity test of adult zebrafish: The acute toxicity test of adult zebrafish was conducted according to the OECD standard test method ${ }^{69}$. All animal experiments conformed to regulatory standards according to protocols approved by the Animal Care Committee of East China University of Science and Technology. Wild type AB zebrafish (weighing $0.4 \pm 0.1 \mathrm{~g}$ ) were fed in the laboratory for 2 weeks to adapt to the environment. The feeding environment was at $28^{\circ} \mathrm{C}$ and the circadian rhythm was 14:10 per day. At the beginning of the experiment, the zebrafish were randomly exposed to $2 \mathrm{~L}$ exposure solution contained peptide polymers at the different concentration. Three repeating groups were used for each concentration and each repeating group contained 10 fish. In order to maintain the oxygen content in the water, the exposure solution was changed every 24 hours. There was no feeding or oxygen supply during the whole experiment. The dead individual was removed immediately. The survival of adult zebrafish was then calculated at 24, 48, 72 and 96 hours. The median lethal concentration $\left(\mathrm{LC}_{50}\right)$ was calculated by probit regression analysis in the IBM SPSS Statistics 26.0 software.

Zebrafish survival assay: Adult zebrafish were randomly divided into three groups (10 fish per group): PBS group, ( $V$. anguillarum $+\mathrm{PBS})$ group and $\left(V\right.$. anguillarum $\left.+\mathrm{K}_{18} \mathrm{~S}_{4}\right)$ group. $V$. anguillarum cultured to the exponential period was washed three times with PBS and then was resuspended in PBS to $4 \times 10^{8} \mathrm{CFU} / \mathrm{mL}$. Subsequently, inoculation was performed by intraperitoneal injection of $10 \mu \mathrm{L}$. anguillarum suspension or 10 $\mu \mathrm{L}$ PBS for the experimental groups and the control group, respectively. After 30 minutes, PBS and $\mathrm{K}_{18} \mathrm{~S}_{4}(20$ $\mathrm{mg} / \mathrm{kg}$ ) were treated for ( $V$. anguillarum $+\mathrm{PBS})$ group and (V. anguillarum $\left.+\mathrm{K}_{18} \mathrm{~S}_{4}\right)$ group, respectively. The survival and the symptoms of infection were observed during the 7-days observation period.

Antimicrobial assay in vivo: V. anguillarum cultured to the exponential period was washed three times with PBS, then the bacteria were resuspended in PBS to $4 \times 10^{8} \mathrm{CFU} / \mathrm{mL}$. Inoculation was performed by intraperitoneal injection of $10 \mu \mathrm{L}$. anguillarum suspension for 50 zebrafish. After 30 minutes, 50 zebrafish were divided into two groups and treated with $\mathrm{K}_{18} \mathrm{~S}_{4}(20 \mathrm{mg} / \mathrm{kg})$ or equal volume of PBS, respectively. 24 hours later, all zebrafish were anesthetized with $0.3 \%$ tricaine and then euthanized. The heart, liver and spleen were taken out by aseptic operation, and the tissues of five fish in each group were mixed into one sample due to the small size. Finally, the 
tissues were homogenized with PBS containing 0.1\% TX100 and plated onto agar for CFU count.

Serum biochemical index: 80 adult zebrafish were randomly divided into two groups, and each was injected intraperitoneally with $\mathrm{K}_{18} \mathrm{~S}_{4}(20 \mathrm{mg} / \mathrm{kg}$ ) or equal volume of PBS. After 24 hours, all zebrafish were anesthetized with $0.3 \%$ tricaine and then euthanized. After euthanasia, zebrafish was quickly dried and the eyeballs were removed immediately by tweezers. The blood was carefully collected with a pipette when it filled the eye socket according to the literature ${ }^{70}$. The blood sample of 10 zebrafish in the same group was mixed into one sample due to the limited amount of blood in each fish. After standing at room temperature for 2 hours, the serum was obtained by centrifugation at $4000 \mathrm{rpm}$ for 5 minutes, and then the serum was transferred to another centrifuge tube and analyzed with a serum biochemical detection instrument.

Statistical analysis: The data of statistical analysis was performed by Origin software. Significance between the two groups was determined by $t$-test. All mean \pm standard deviation was indicated by the error bars.

\section{References}

1. Stanton, T.B. Treatment, promotion, commotion: antibiotic alternatives in food-producing animals. Trends Microbiol. 21, 111113 (2013).

2. Van Boeckel, T.P. et al. Global trends in antimicrobial resistance in animals in low- and middle-income countries. Science $\mathbf{3 6 5}$ (2019).

3. Van Boeckel, T.P. et al. Global trends in antimicrobial use in food animals. Proc. Natl. Acad. Sci. U. S. A. 112, 5649-5654 (2015).

4. Boeckel, T.V. et al. Reducing antimicrobial use in food animals. Science 357, 1350-1352 (2017).

5. Andersson, D.I. \& Hughes, D. Microbiological effects of sublethal levels of antibiotics. Nat. Rev. Microbiol. 12, 465-478 (2014).

6. Chen, J. et al. Antibiotics and Food Safety in Aquaculture. J. Agric. Food Chem. 68, 11908-11919 (2020).

7. Ben, Y. et al. Human health risk assessment of antibiotic resistance associated with antibiotic residues in the environment: A review. Environ. Res. 169, 483-493 (2019).

8. Munk, P. et al. Abundance and diversity of the faecal resistome in slaughter pigs and broilers in nine European countries. Nat. Microbiol. 3, 898-908 (2018).

9. Reverter, M. et al. Aquaculture at the crossroads of global warming and antimicrobial resistance. Nat. Commun. 11 (2020).

10. Cabello, F.C., Godfrey, H.P., Buschmann, A.H. \& Dölz, H.J. Aquaculture as yet another environmental gateway to the development and globalisation of antimicrobial resistance. Lancet Infect. Dis. 16, e127-e133 (2016).

11. Schar, D., Klein, E.Y., Laxminarayan, R., Gilbert, M. \& Van Boeckel, T.P. Global trends in antimicrobial use in aquaculture. Sci. Rep. 10, 21878 (2020).

12. Deng, W., Li, N., Zheng, H. \& Lin, H. Occurrence and risk assessment of antibiotics in river water in Hong Kong. Ecotoxicol. Environ. Safe. 125, 121-127 (2016).

13. Shi, H. et al. Occurrence and distribution of antibiotics in the surface sediments of the Yangtze Estuary and nearby coastal areas. Mar. Pollut. Bull. 83, 317-323 (2014).

14. Hendriksen, R.S. et al. Global monitoring of antimicrobial resistance based on metagenomics analyses of urban sewage. Nat. Commun. 10, 1124 (2019).

15. O'Neill, J. Antimicrobial Resistance: Tackling a crisis for the health and wealth of nations. (2014).

16. Zhou, M. et al. Antibiotics control in aquaculture requires more than antibiotic-free feeds: A tilapia farming case. Environ. 
Pollut. 268, 115854 (2021).

17. Shen, Y. et al. Anthropogenic and environmental factors associated with high incidence of mcr-1 carriage in humans across China. Nat. Microbiol. 3, 1054-1062 (2018).

18. Hu, Y.J. \& Cowling, B.J. Reducing antibiotic use in livestock, China. Bull. W. H. O. 98, 360-361 (2020).

19. Lulijwa, R., Rupia, E.J. \& Alfaro, A.C. Antibiotic use in aquaculture, policies and regulation, health and environmental risks: a review of the top 15 major producers. Rev. Fish. Sci. 12, 640-663 (2019).

20. Laxminarayan, R. et al. Access to effective antimicrobials: a worldwide challenge. Lancet 387, 168-175 (2016).

21. Sommerset, I., Krossoy, B., Biering, E. \& Frost, P. Vaccines for fish in aquaculture. Expert Rev Vaccines 4, 89-101 (2005).

22. Liu, X. et al. Design and evaluation of an Edwardsiella tarda DNA vaccine co-encoding antigenic and adjuvant peptide. Fish Shellfish Immunol. 59, 189-195 (2016).

23. Verschuere, L., Rombaut, G., Sorgeloos, P. \& Verstraete, W. Probiotic Bacteria as Biological Control Agents in Aquaculture. Microbiol. Mol. Biol. Rev. 64, 655-671 (2000).

24. Perez-Sanchez, T., Mora-Sanchez, B. \& Balcazar, J.L. Biological Approaches for Disease Control in Aquaculture: Advantages, Limitations and Challenges. Trends Microbiol. 26, 896-903 (2018).

25. Defoirdt, T., Boon, N., Sorgeloos, P., Verstraete, W. \& Bossier, P. Short-chain fatty acids and poly-beta-hydroxyalkanoates: (New) Biocontrol agents for a sustainable animal production. Biotechnol. Adv. 27, 680-685 (2009).

26. Defoirdt, T., Sorgeloos, P. \& Bossier, P. Alternatives to antibiotics for the control of bacterial disease in aquaculture. Curr. Opin. Microbiol. 14, 251-258 (2011).

27. Dai, J. et al. The effect of dietary cecropin AD on intestinal health, immune response and disease resistance of juvenile turbot (Scophthalmus maximus L.). Fish Shellfish Immunol. 100, 117-125 (2020).

28. Valero, Y., Saraiva - Fraga, M., Costas, B. \& Guardiola, F.A. Antimicrobial peptides from fish: beyond the fight against pathogens. Rev Aquac 12, 224-253 (2018).

29. Reverter, M., Bontemps, N., Lecchini, D., Banaigs, B. \& Sasal, P. Use of plant extracts in fish aquaculture as an alternative to chemotherapy: Current status and future perspectives. Aquaculture 433, 50-61 (2014).

30. Doan, H.V., Soltani, E., Ingelbrecht, J. \& Soltani, M. Medicinal Herbs and Plants: Potential Treatment of Monogenean Infections in Fish. Rev. Fish. Sci. 28, 260-282 (2020).

31. El-Houseiny, W. et al. Silver nanoparticles mitigate Aeromonas hydrophila-induced immune suppression, oxidative stress, and apoptotic and genotoxic effects in Oreochromis niloticus. Aquaculture 535 (2021).

32. Yostawonkul, J. et al. Bifunctional clove oil nanoparticles for anesthesia and anti-bacterial activity in Nile tilapia (Oreochromis niloticus). Aquaculture 503, 589-595 (2019).

33. Mizutani, M. et al. Design and synthesis of self-degradable antibacterial polymers by simultaneous chain- and step-growth radical copolymerization. Biomacromolecules 13, 1554-1563 (2012).

34. Krumm, C. et al. Fast-Acting Antibacterial, Self-Deactivating Polyionene Esters. ACS Appl. Mater. Interfaces 12, 21201-21209 (2020).

35. Yang, C. et al. Degradable antimicrobial polycarbonates with unexpected activity and selectivity for treating multidrug-resistant Klebsiella pneumoniae lung infection in mice. Acta Biomater. 94, 268-280 (2019).

36. Walsh, T.R. \& Wu, Y. China bans colistin as a feed additive for animals. The Lancet Infectious Diseases 16, 1102-1103 (2016).

37. Wang, Y. et al. Comprehensive resistome analysis reveals the prevalence of NDM and MCR-1 in Chinese poultry production. Nat Microbiol 2, 16260 (2017).

38. Porter, E.A., Wang, X.F., Lee, H.S., Weisblum, B. \& Gellman, S.H. Antibiotics: Non-haemolytic $\beta$-amino-acid oligomers. Nature 404, 565 (2000).

39. Mowery, B.P. et al. Mimicry of antimicrobial host-defense peptides by random copolymers. J. Am. Chem. Soc. 129, 1547415476 (2007).

40. Kuroda, K. \& Degrado, W.F. Amphiphilic polymethacrylate derivatives as antimicrobial agents. J. Am. Chem. Soc. 127, 41284129 (2005).

41. Chin, W. et al. A macromolecular approach to eradicate multidrug resistant bacterial infections while mitigating drug resistance 
onset. Nat. Commun. 9, 917 (2018).

42. Uppu, D.S.S.M. et al. Polymers with tunable side-chain amphiphilicity as non-hemolytic antibacterial agents. Chem. Commun. 49, 9389-9391 (2013).

43. Zhang, K. et al. Enantiomeric glycosylated cationic block co-beta-peptides eradicate Staphylococcus aureus biofilms and antibiotic-tolerant persisters. Nat. Commun. 10, 4792 (2019).

44. Krumm, C. et al. Antimicrobial poly(2-methyloxazoline)s with bioswitchable activity through satellite group modification. Angew. Chem., Int. Ed. 53, 3830-3834 (2014).

45. Li, X. et al. Supramolecular Antibacterial Materials for Combatting Antibiotic Resistance. Adv. Mater. (2018).

46. Xiong, M. et al. Helical antimicrobial polypeptides with radial amphiphilicity. Proc. Natl. Acad. Sci. U. S. A. 112, 13155-13160 (2015).

47. Wu, H. et al. Design and synthesis of unprecedented cyclic $\gamma$-AApeptides for antimicrobial development. Chem. Sci. 3 (2012).

48. Zhou, M. et al. Poly(2-Oxazoline)-Based Functional Peptide Mimics: Eradicating MRSA Infections and Persisters while Alleviating Antimicrobial Resistance. Angew. Chem., Int. Ed. 59, 6412-6419 (2020).

49. Zhang, Q. et al. Host defense peptide mimicking poly-beta-peptides with fast, potent and broad spectrum antibacterial activities. Biomater. Sci. 7, 2144-2151 (2019).

50. Sun, J., Li, M., Lin, M., Zhang, B. \& Chen, X. High Antibacterial Activity and Selectivity of the Versatile Polysulfoniums that Combat Drug Resistance. Adv. Mater. 33, e2104402 (2021).

51. $\mathrm{Wu}, \mathrm{Y}$. et al. Lithium hexamethyldisilazide initiated superfast ring opening polymerization of alpha-amino acid $\mathrm{N}$ carboxyanhydrides. Nat. Commun. 9, 5297 (2018).

52. Jiang, W. et al. Peptide polymer displaying potent activity against clinically isolated multidrug resistant Pseudomonas aeruginosa in vitro and in vivo. Biomater. Sci. 8, 739-745 (2020).

53. Kito, M., Onji, Y., Yoshida, T. \& Nagasawa, T. Occurrence of $\varepsilon$-poly-L-lysine-degrading enzyme in $\varepsilon$-poly-L-lysine-tolerant Sphingobacterium multivorum OJ10: purification and characterization. FEMS Microbiol. Lett. 207, 147-151 (2002).

54. Choi, H., Yang, Z. \& Weisshaar, J.C. Single-cell, real-time detection of oxidative stress induced in Escherichia coli by the antimicrobial peptide CM15. Proc. Natl. Acad. Sci. U. S. A. 112, E303-310 (2015).

55. Kim, S.Y. et al. Antibacterial strategies inspired by the oxidative stress and response networks. J. Microbiol. 57, 203-212 (2019).

56. Hong, Y., Zeng, J., Wang, X., Drlica, K. \& Zhao, X. Post-stress bacterial cell death mediated by reactive oxygen species. Proc. Natl. Acad. Sci. U. S. A. 116, 10064-10071 (2019).

57. Martinez, S.R., Durantini, A.M., Becerra, M.C. \& Cosa, G. Real-Time Single-Cell Imaging Reveals Accelerating Lipid Peroxyl Radical Formation in Escherichia coli Triggered by a Fluoroquinolone Antibiotic. ACS Infect. Dis. 6, 2468-2477 (2020).

58. Dong, T.G. et al. Generation of reactive oxygen species by lethal attacks from competing microbes. Proc. Natl. Acad. Sci. U. S. A. 112, 2181-2186 (2015).

59. Sochacki, K.A., Barns, K.J., Bucki, R. \& Weisshaar, J.C. Real-time attack on single Escherichia coli cells by the human antimicrobial peptide LL-37. Proc. Natl. Acad. Sci. U. S. A. 108, E77-81 (2011).

60. Rank, L.A. et al. Diverse Impacts on Prokaryotic and Eukaryotic Membrane Activities from Hydrophobic Subunit Variation Among Nylon-3 Copolymers. ACS Chem. Biol. 16, 176-184 (2021).

61. Awad, E. \& Awaad, A. Role of medicinal plants on growth performance and immune status in fish. Fish Shellfish Immunol. 67, 40-54 (2017).

62. Adams, A. Progress, challenges and opportunities in fish vaccine development. Fish Shellfish Immunol. 90, 210-214 (2019).

63. Habraken, G.J.M., Peeters, M., Dietz, C.H.J.T., Koning, C.E. \& Heise, A. How controlled and versatile is N-carboxy anhydride (NCA) polymerization at $0{ }^{\circ} \mathrm{C}$ ? Effect of temperature on homo-, block- and graft (co)polymerization. Polym. Chem. 1, 514524 (2010).

64. Song, A., Rane, A.A. \& Christman, K.L. Antibacterial and cell-adhesive polypeptide and poly(ethylene glycol) hydrogel as a potential scaffold for wound healing. Acta Biomater. 8, 41-50 (2012).

65. Lee, H., Park, J.B. \& Chang, J.Y. Synthesis of poly(ethylene glycol)/polypeptide/poly(D,L-lactide) copolymers and their nanoparticles. J. Polym. Sci., Part A: Polym. Chem. (2011). 
66. Zhou, M. et al. Water-Insensitive Synthesis of Poly-beta-Peptides with Defined Architecture. Angew. Chem., Int. Ed. 59, 72407244 (2020).

67. Konstantinova, T., Lazarova, R., Venkova, A. \& Vassileva, V. On the synthesis and photostability of some new naphthalimide dyes. Polym. Degrad. Stab. 84, 405-409 (2004).

68. Miao, Q. et al. Molecular afterglow imaging with bright, biodegradable polymer nanoparticles. Nat. Biotechnol. 35, 1102-1110 (2017).

69. OECD Guidelines for the testing of chemicals. Section 2: Effects on Biotic Systems. Test No. 203: Fish, Acute Toxicity Testing. Organization for Economic Cooperation and Development, Paris. (2019).

70. Vliegenthart, A.D. et al. Retro-orbital blood acquisition facilitates circulating microRNA measurement in zebrafish with paracetamol hepatotoxicity. Zebrafish 11, 219-226 (2014).

\section{Acknowledgements}

This research was supported by the National Natural Science Foundation of China for Innovative Research Groups (No. 51621002), the National Natural Science Foundation of China (No. 22075078, 21861162010), the National Key Research and Development Program of China (2016YFC1100401), Program of Shanghai Academic/Technology Research Leader (20XD1421400), the Natural Science Foundation of Shanghai (18ZR1410300), Research program of State Key Laboratory of Bioreactor Engineering, the Fundamental Research Funds for the Central Universities. The authors thank Wenwen Wang and professor Qin Liu at East China University of Science and Technology for their help on zebrafish breeding, the Research Center of Analysis and Test of East China University of Science and Technology for the help on the characterization, and ZEISS Microscopy Shanghai Customer Center for the help with the confocal microscopy.

\section{Author contributions}

R.L. directed the whole project. P.M. and R.L. conceived the idea, proposed the strategy, designed the experiments, evaluated the data, and wrote the manuscript together. P.M. performed the majority of the experiments. Y.W. performed the exploration of polymerization methods and the characterization of peptide polymers. W.J. and Y.C. participated in the animal study; N.S. performed the cytotoxicity assays; M.Z. conducted the time-lapse fluorescent confocal imaging; J.X. and Z.Q. conducted the scanning electron microscope imaging. All authors participated in the discussion of the results and commented on the manuscript.

\section{Competing interests}

The authors declare the following competing financial interest (s): R.L. and P.M. are co-inventors on a patent application covering reported materials and application on alternatives to antibiotics in aquaculture. All remaining authors declare no competing interests. 


\section{TOC}

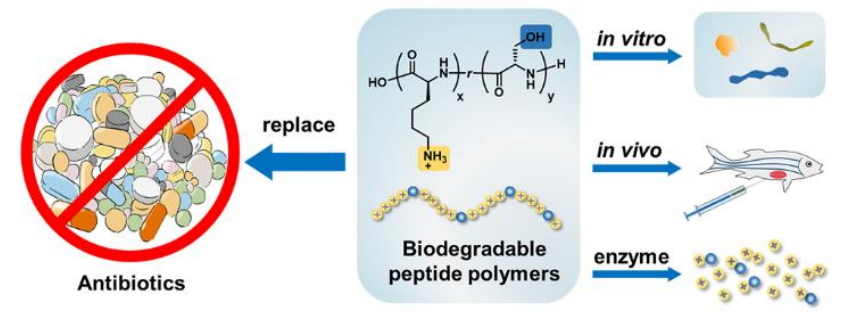

